\title{
„ZACZĘLAM FILOZOFOWAĆ, ROZMYŚLAĆ, SZUKAĆ ODPOWIEDZI NA DRĘCZĄCE MNIE KWESTIE". WSPOMNIENIA EDWARDY (ETLI) BOMSZTYK: BIOGRAFIA, EMANCYPACJA, POLITYKA
}

\section{PIOTR LASKOWSKI}

\begin{abstract}
Abstrakt: Trzyczęściowe wspomnienia Etli (Edwardy) Bomsztyk (1899-1973) są świadectwem o szczególnym znaczeniu, zapisem losu kobiety, Żydówki, służącej. Dwie części - jedna opublikowana w języku żydowskim w 1959 roku, druga nagrana w języku polskim w roku 1966 i przechowywana w Archiwum Akt Nowych - dotyczą działalności politycznej autorki: organizatorki związków zawodowych pomocy domowych w Warszawie w okresie międzywojennym, członkini Bundu i KPP, wreszcie - więźniarki politycznej. Trzecia relacja, spisana po polsku w roku 1953, zachowana poza kontekstem instytucjonalnym i nigdy niepublikowana, jest świadectwem bardzo osobistym: opowiada o dzieciństwie w żydowskim miasteczku, przyjédzie do Warszawy, nędzy i cierpieniu, pierwszych lekturach, osamotnieniu i buncie. Celem artykułu jest ujawnienie napięcia między opowieściami dotyczącymi politycznego zaangażowania a narracją o doświadczeniach, które stanowiąc podglebie owego zaangażowania, pozostawały zarazem niewypowiadalne w ramach praktyk dyskursywnych wypracowanych przez ruch komunistyczny.
\end{abstract}

Słowa kluczowe: Edwarda (Etla) Bomsztyk, służba domowa, historia ludowa, historia Żydów, historia kobiet 


\section{Panu Mirosławowi Gaszçzynskiemu}

Wśród robotniczych relacji biograficznych trzyczęściowe wspomnienia Etli (Edwardy) Bomsztyk (1899-1973) są świadectwem zasługującym na szczególną uwagę. Obejmują trzydzieści lat życia: naznaczone nędzą dzieciństwo w żydowskim miasteczku w pierwszej dekadzie dwudziestego wieku, wyjazd za chlebem do Warszawy w wieku lat czternastu, pracę w służbie domowej w czasie I wojny światowej, organizowanie związków zawodowych służących po roku 1918, zaangażowanie partyjne - najpierw w Bundzie, później w Komunistycznej Partii Polski - kolejne aresztowania, wreszcie dwuletnie uwięzienie w latach 1932-1934.

Trzy części wspomnień - opowieść o latach młodzieńczych kończąca się na roku 1918, relacja z działalności związkowej i politycznej w pierwszym dziesięcioleciu II Rzeczypospolitej oraz opis życia więziennego - doskonale się uzupełniaja, ale każda ma własną historię: jedna była już publikowana, oryginalnie w języku żydowskim (jidysz) ${ }^{1}$, później w tłumaczeniu polskim, spośród dwóch pozostałych, spisanych w języku polskim i dotąd niepublikowanych, jedna znajduje się w Archiwum Akt Nowych w Warszawie, druga pochodzi z domowego archiwum córki Etli Bomsztyk. Zebranie ich po raz pierwszy w całość w Aneksie do niniejszego artykułu było możliwe dzięki Mirosławowi Gaszczyńskiemu, Annie Ciałowicz i Andrzejowi Grzybowskiemu - to oni ocalili wspomnienia Etli Bomsztyk przed zniszczeniem lub zapomnieniem ${ }^{2}$.

Etla Bomsztyk, kobieta, Żydówka, służąca lub raczej - jak woli mówić - „,robotnica domowa", jest częścia świata, który dla historiografii pozostaje niemy. Co pozwoliło jej mówić? Czy naprawdę może przemówić?

\section{„Milczenie archiwów”}

Przed ponad pół wiekiem François Furet rozpoczął swój głośny artykuł poświęcony pytaniu o miejsce grup podporządkowanych w historii obserwacją:

Dla historii - i wczoraj, i dziś - pojęcie klas niższych kojarzy się przede wszystkim z liczbą i anonimowością. Człowiek z klas niższych istnieje dla historyków wyłącznie o tyle, o ile ginie w studiach demograficznych czy socjologicznych, natomiast przez historię szlachetną, która przez długi czas była historią jedyną - tę, która docenia

\footnotetext{
${ }^{1}$ Jakkolwiek mianem języków żydowskich określa się często grupę języków, którymi posługiwali się Żydzi (wśród nich jidysz, ladino, także hebrajski), w niniejszym artykule - zgodnie z zasadą zastosowaną m.in. w pełnej edycji Archiwum Ringelbluma - termin ,język żydowski” odnosi się wyłącznie do języka jidysz.

${ }^{2} \mathrm{~W}$ dalszej części artykułu staram się choć w drobnej części zaznaczyć wkład, jaki wnieśli w jego powstanie. Podziękowania są dalece niewystarczającym wyrazem wdzięczności za ich trud i życzliwość.
} 
i wynagradza osobowość - był ignorowany. Historia dzisiejsza ponownie włącza go w ludzka przygodę poprzez ilościowe badanie społeczeństw przeszłości: ale pozostaje on w niej milczący (Furet 1963, 459).

Jakkolwiek rozwój badań mikrohistorycznych w latach siedemdziesiątych radykalnie zmienił ten stan rzeczy, anulując opozycję osobowości i liczby (por. Ginzburg 1989, 16 i n.), historii społecznej i histoire noble, wciąż jeszcze dzieje niezliczonych istnień ludzkich historiografia ujmuje - potrafi ująć - jedynie metodami demograficznymi, pod znakiem „liczby i anonimowości”. Wciąż bowiem musimy się mierzyć z „milczeniem archiwów” (Perrot 1998, 12). Niemal sto lat temu Eileen Power, zacytowawszy obserwację Lorda Actona, że „obecnie wielki historyk jada w kuchni”, zauważyła przenikliwie, iż „niewiele przyjdzie z jedzenia w kuchni, jeśli nigdy nie rozmawia się ze służbą" (Power 1924, 2 i 10). Nie wystarczy więc przyznać, że historię tworzy swą pracą „lud jako całość, bezimienne i niezróżnicowane ludzkie masy, spoczywające dziś w nieznanych grobach" (Power 1924, 2), trzeba pytać o ich uczucia i myśli (Power 1924, 10). Power, kreśląc sześć portretów ludzi średniowiecza - ludzi, którzy „z wyjątkiem Marco Polo byli całkiem zwyczajni i nie zaznali sławy” (Power 1924, VIII) - wskazywała, że „często materiał, jaki mamy do dyspozycji, pozwala w tym samym stopniu na rekonstrukcję życia jakiejś zwyczajnej osoby, co na napisanie historii Roberta z Normandii czy Filipy de Hainault” (Power 1924, VII). Ten optymizm okazał się jednak nadmierny, a użytek, jaki Power czyniła z dostępnych źródeł - nie do końca przekonujący. Szczególnie trudne okazało się pisanie historii kobiet. Jak zauważył Carlo Ginzburg, jedyne dwie kobiece bohaterki jej książki „pochodzą z dwóch bardzo różnych tekstów literackich, w obu przypadkach napisanych przez mężczyzn” (Ginzburg 1991, 87-89).

„Na początku było Słowo, lecz Bogiem było Słowo, i Mężczyzną. Milczenie to dla kobiet rzecz zwykła. Pasuje do ich pozycji - drugoplanowej i podporządkowanej” - pisała Michelle Perrot (Perrot 1998, 1) we wstępie do książkowej edycji esejów, w których wciąż na nowo podejmuje walkę $\mathrm{z}$ ciszą spowijająca kobiety $\mathrm{w}$ historii. Choć ostatnie dekady przyniosły niezwykłe zmiany, gdy idzie o zainteresowania historiografii - także w Polsce, by wspomnieć tylko przełomowe osiem tomów studiów Kobieta i..., wydanych między rokiem 1990 a 2004 pod redakcją Anny Żarnowskiej i Andrzeja Szwarca - wciąż musimy konfrontować się z „milczeniem archiwów”, z wszechobecnym w nich „spojrzeniem mężczyzn na mężczyzn” (Perrot 1998, 13). „W teatrze pamięci kobiety są bladym cieniem”, zauważa Perrot w eseju z roku 1987, poświęconym możliwościom badania „praktyk kobiecej pamięci”, praktyk specyficznych, osobnych, albowiem „pamięć, forma stosunku do czasu i przestrzeni, podobnie jak egzystencja, której jest przedłużeniem, jest głęboko upłciowiona” (Perrot 1998; 11, 20).

Specyfika praktyk pamięci, pamięci wytłumianej i spychanej w otchłań ciszy, czyni problematycznymi pytania, które współczesne historyczki i historycy stawiają kobietom 
przeszłości. Natalie Zemon Davis w przejmujący sposób ujawnia relację między silnym głosem historyczki i bladym cieniem pamięci, poprzedzając Kobiety na marginesach wyobrażonym dialogiem, jaki prowadzi ze swymi bohaterkami, kwestionującymi jej założenia badawcze i powtarzającymi: „O tym akurat lepiej milczeć” (Zemon Davis 2012, 9).

A przecież trzy kobiety, których życie bada Zemon Davis, są kobietami pióra. „Uwielbiają pisać”, pozostawiają po sobie bądź autobiografię, bądź zapis duchowych doświadczeń, bądź dzieła naukowe. Celem niniejszego artykułu jest podjęcie zalecenia Power, by „rozmawiać ze służbą” - zalecenia, które chcemy rozumieć absolutnie dosłownie. Bo też praca służącej jest w interesującym nas okresie - w pierwszych dekadach dwudziestego wieku - najpowszechniejszą w kontynentalnej Europie formą zatrudnienia kobiet pracujących poza rolnictwem (Kopczyński 2000, 71; dla Polski - Mierzecki 2000, 111). W przededniu Wielkiej Wojny we Francji pracuje milion służących, 75\% z nich to kobiety. „W 1906 r. na sto kobiet aktywnych zawodowo siedemdziesiąt to służące, w wielkich miastach nawet więcej. W Paryżu, gdzie jest w tym czasie dwieście tysięcy służących (11\% populacji), brakuje rąk do tej pracy, co wiąże się z bogaceniem się stolicy" (Perrot 1998, 194). Służba domowa stanowi więc najbardziej powszechne doświadczenie pracy kobiet w mieście, czy mówiąc precyzyjniej, najbardziej powszechne doświadczenie pracy najemnej, a zatem takiej, która miałaby - jak sądzili apologeci nowoczesności - emancypować kobiety, wyrywać je z ograniczeń życia wiejskiego czy domowego. A przecież praca służącej spycha kobiety niemal na samo dno społecznej hierarchii. Perrot zauważała:

\begin{abstract}
Bez watpienia ryzykownym byłoby twierdzenie [...], że służba domowa to dla kobiet sposób awansu społecznego. Gruźlica, syfilis [...], prostytucja - również to jest ich losem. Korzyścią ich położenia jest uzyskiwanie pieniędzy, lecz towarzyszą mu oburzające warunki materialne, nieznośna podległość i dramatyczna niekiedy samotność (Perrot 1998, 195).
\end{abstract}

Praca służącej bywała nierzadko lekceważona przez badaczy historii społecznej, skupionych w duchu ortodoksyjnego marksizmu, zbieżnego tu z ekonomią liberalna (Poniat 2014, 60-62) - na pracy produkcyjnej i związanych z nia formach upodmiotowienia (nie przypadkiem Perrot powtarza niestrudzenie, że „kobiety pracowały zawsze”, np. Perrot 1998, 201). Służba

\footnotetext{
${ }^{3} \mathrm{Na}$ problemy definicyjne związane z kategorią służby domowej zwraca uwagę Michał Kopczyński (2000, 53-57). Kreśli on jednak szeroki obraz rozwoju tej grupy społecznej od piętnastego do dwudziestego wieku. W niniejszym artykule zajmujemy się jedynie służbą domową zatrudnianą w domach mieszczańskich w pierwszych dekadach dwudziestego wieku, a zatem grupa już dość jednorodna tak pod względem społecznym (kobiety z niższych warstw społecznych, pochodzące przede wszystkim ze wsi i małych miasteczek; Kopczyński 2000, 59 i 75), warunków pracy (praca najemna, powiązana zazwyczaj z zamieszkiwaniem w domu pracodawcy, jakkolwiek w separacji od zatrudniającej rodziny; Kopczyński 2000, 60-61), jak i pod względem wykonywanych prac (zakupy, sprzątanie, pranie i czyszczenie ubrań, niekiedy gotowanie; por. Piotrowska-Marchewa 2009, 198).
} 
domowa jako grupa wykonująca pracę reprodukcyjna, zawieszoną w niebycie między domem a aktywnością wytwórcza, była pomijana jako ostatecznie nienależąca do klasy robotniczej. Niemałe znaczenie miał przy tym niski poziom upolitycznienia tej grupy. „Służba domowa stanowiła [...] szczególna grupe zawodowa, wyróżniającą się wśród innych grup pracownic najemnych [...] niejasnym statusem społecznym i słabo postrzeganą przynależnością klasową" (Mierzecki 2000, 111). Historiografia długo nie rozpoznawała więc służących jako odrębnego podmiotu ekonomicznego czy politycznego.

\begin{abstract}
Wysoki poziom analfabetyzmu, rozproszenie $\mathrm{w}$ izolowanych od siebie gospodarstwach domowych i związana z tym zależność od pracodawców sprawiały, że służba domowa w bardzo małym stopniu uświadamiała sobie swoją przynależność do warstwy robotniczej. Problemy z samoidentyfikacja »klasowa« przekładały się na niski poziom jej zaangażowania w robotniczy, klasowy ruch związkowy (Piotrowska-Marchewa 2009, 209).
\end{abstract}

Ostatecznie więc to właśnie „naukowcy przyczynili się do ukrycia historii i praktyki pracy domowej za murami prywatnych domostw" (Nederveen Meerkerk, Neunsinger i Hoerder 2015, 5-6). Dopiero włączenie do praktyki historiograficznej dorobku myśli feministycznej pozwoliło dostrzec służbę domową jako grupę wymagającą osobnych badań ${ }^{4}$.

W ostatnich latach zaczęto więc o służących pisać, a Michał Kopczyński zauważał nawet prowokacyjnie:

\begin{abstract}
Wertując ponad 30 pozycji bibliograficznych dotyczących służby domowej, niemal zawsze we wstępie natykałem się na uwage, że ta grupa zawodowa pozostaje mało znana, bo zainteresowania historyków kierują się ku bardziej efektownym warstwom społecznym. Sam fakt, że w trakcie pobieżnej kwerendy natrafiłem na kilkadziesiąt pozycji poświęconych wyłącznie służbie, przeczy temu poglądowi (Kopczyński 2000, 53).
\end{abstract}

A jednak same służące pozostaja zazwyczaj nieme. Podstawowym źródłem wykorzystywanym w badaniach są spisy ludności (Kopczyński 2000, 55). Stąd Radosław Poniat, autor pierwszej w języku polskim obszernej monografii poświęconej służbie domowej, opublikowanej ledwie trzy lata temu, mógł stwierdzić: „jesteśmy w stanie powiedzieć zaskakująco niewiele na temat grupy nie tylko stanowiącej poważną część historycznych społeczności, ale też odgrywającej niezwykle istotną rolę w ich

\footnotetext{
4 Proces włączania służby domowej w pole zainteresowania zachodniej historiografii opisała - dając użyteczny przegląd podstawowych tekstów - Raffaella Sarti (2015, 25-60).
} 
funkcjonowaniu” (Poniat 2014, 9). Główną przyczyną tego stanu jest właśnie „brak podstawowych nawet źródeł”:

jak na tak powszechnie występująca grupę społeczną, służba jest zaskakująco słabo reprezentowana w zachowanych do naszych czasów dokumentach. Specyfika pozycji służby, jej przynależność do dołów społecznych i funkcjonowanie w ramach prywatnego świata gospodarstw domowych spowodowały, iż bardzo często źródła milczą na jej temat (Poniat 2014, 10).

Jeden z podrozdziałów pracy Poniata nosi wręcz tytuł Milczenie o stu̇̇bie (Poniat 2014, 59 i n.). Dodajmy, że jeżeli nawet źródła nie milczą o służbie, to służba milczy w źródłach - obecna w nich niemal wyłącznie poprzez spojrzenie z zewnątrz - spojrzenie różnych poziomów władzy 5 .

Nie jest więc przypadkiem, że obraz służby domowej na ziemiach polskich, jaki wyłania się z istniejących opracowań, to obraz ilościowy, spod znaku ,anonimowości i liczby". W Polsce piszą o służących przede wszystkim badacze zajmujący się demografią historyczną i historią społeczno-gospodarczą. Znamienne, że nawet dysponując źródłem tak niezwykłym, jak wspomnienia Józefy Witowskiej, czynią z niego bardzo ograniczony użytek, deklarując raczej, że „dla historyka gospodarczego nie ma nic tak pięknego, jak dobrze zrobiony wykres” (Poniat 2014, 13). Podstawowym źródłem dla okresu II Rzeczypospolitejktóry będzie nas szczególnie interesował - pozostają zatem dane z dwóch spisów powszechnych przeprowadzonych w 1921 i 1931 roku$^{6}$. Pracę służącej wykonywały w tym okresie w zasadzie wyłącznie kobiety (Żarnowski 1999, 409) ${ }^{7}$. Służące stanowiły niemal połowę (odpowiednio 44,1\% i 46,3\%) spośród objętych spisami, czynnych zawodowo i zatrudnionych poza rolnictwem kobiet z warstwy robotniczej (Mierzecki 2000, 119) ${ }^{8}$ i nieco

\footnotetext{
${ }^{5}$ Poniat $(2014,19-23)$ wyróżnił cztery podstawowe grupy źródeł pozwalających badać służbę domową: akty normatywne (kodeksy, ustawy, rozporządzenia władz), źródła demograficzne (spisy ludności), źródła sądowe i policyjne oraz prasę i publicystykę (w tym poradniki kierowane zarówno do osób zatrudniających służbę, jak i do samych służących). Osobną kategorią są pamiętniki, przy czym - jak zauważa Poniat - grupą tworząca je sa przeważnie osoby zatrudniające służbę. Wyjątkowe znaczenie na gruncie polskim ma pamiętnik Józefy Witowskiej (Witowska 1951). Do tego zestawienia dodać można teksty literackie, opatrując je podobnym zastrzeżeniem, co pamiętniki - w tym wypadku grupą tworzącą źródło są wyłącznie przedstawiciele klas wyższych.

6 Problem porównywalności danych z obu spisów omawia Janusz Żarnowski (2000, 96-98), zwracając uwage m.in. na różnice między obszarami objętymi spisem.

${ }^{7}$ Warto przy tym zauważyć, że radykalny skok w zakresie feminizacji służby domowej w Warszawie dokonał się dopiero w dwudziestym wieku - podczas gdy w roku 1882 i 1897 odsetek mężczyzn wśród ogółu służących wynosił nieco ponad 20\% (co daje współczynnik feminizacji odpowiednio 339 i 358), to w roku 1921 w służbie pracowało już jedynie 2,2\% mężczyzn (współczynnik feminizacji 4394; zob. Poniat 2014, 140).

${ }^{8}$ Kategoria „robotnice” stanowi zarówno w 1921 jak i 1931 r. 50\% wszystkich kobiet czynnych zawodowo i zatrudnionych poza rolnictwem. Na pozostałe 50\% składają się kobiety samodzielne (zatrudniające
} 
ponad 23\% (w obu spisach) wśród wszystkich kobiet aktywnych zawodowo i pracujących poza rolnictwem (Żarnowski 2000, 98). O ile więc odsetek w zasadzie się nie zmienił, liczba odnotowanych w spisach kobiet zatrudnionych poza rolnictwem wzrosła znaczaco z 1062000 do 1674000 osób. Zatem o ile wedle spisu z 1921 roku w Polsce pracowało około 250 tysięcy służących, dziesięć lat później ich liczba sięgała już prawie 400 tysięcy (Żarnowski 2000, 97-98), w roku 1938 zaś być może nawet 450 tysięcy (Żarnowski 1999, 409). W Warszawie odsetek służących pośród robotnic był nieco wyższy niż w skali kraju: 46\% w 1921 i 48,2\% w 1931 roku (Mierzecki 2000, 119). W 1926 roku służące zatrudniano w co siódmym-ósmym domu w Warszawie (Piotrowska-Marchewa 2009, 199).

Kim były te kobiety? Około 90\% służących w Warszawie okresu międzywojennego to osoby stanu wolnego (Mierzecki 2000, 111), młode (zazwyczaj przed 30 rokiem życia) i niewykształcone (często nieumiejące nawet czytać; Piotrowska-Marchewa 2009, 209). Mieszkały w domach pracodawców i nie mogły liczyć na wsparcie rodziny, zazwyczaj były ekonomicznymi migrantkami przybywającymi do miasta ze wsi i miasteczek. Nie podlegały w zasadzie żadnej ochronie prawnej. „Służba domowa w II Rzeczypospolitej stała się jedną z najsłabszych warstw zawodowych pod względem warunków pracy i zabezpieczeń socjalnych. Jej sytuacja prawna i położenie materialne nie miały właściwie analogii z warunkami żadnej innej grupy pracowniczej międzywojennej Polski” (PiotrowskaMarchewa 2009, 197). Służących nie obejmowało prawo pracy, a planowana już w 1919-1920 roku osobna ustawa o służbie domowej nie została nigdy uchwalona (zob. PiotrowskaMarchewa 2009, 212-213). W efekcie długość dnia roboczego sięgała 14-18 godzin (Piotrowska-Marchewa 2009, 200). Pewną ochronę zapewnił służącym (których zresztą nie wyróżniał jako osobnej grupy) dopiero wydany w roku 1933 roku Kodeks zobowiązań. $\mathrm{Na}$ jego podstawie mogły domagać się czasu wolnego i urlopu ${ }^{9}$, wynagrodzenia i opieki w czasie choroby ${ }^{10}$ oraz - w przypadku, gdy mieszkały u pracodawców - godziwych warunków zakwaterowania ${ }^{11}$. Kodeks zobowiązywał też zatrudniających do zapewnienia elementarnych warunków bezpieczeństwa, co zaowocowało m.in. wprowadzeniem pasów zabezpieczających przed upadkiem z okna ${ }^{12}$.

O upadkach z okien gazety piszą niemal bez przerwy. To jeden z nielicznych momentów, kiedy poznajemy konkretne imiona. Jednak i tu służące skazane są na milczenie. Podejrzewa

i niezatrudniające pracowników najemnych), pracownice umysłowe, pomagające członkinie rodzin oraz kobiety o „nieokreślonym stanowisku społecznym” (Żarnowski 2000, 98).

${ }^{9}$ Dziennik Ustaw nr 82, 28 października 1933, Kodeks zobowiązań, art. 464, 465.

10 Tamże, art. 458, 462 i 463.

11 Tamże, art. 461, par. 2.

12 Tamże, art. 461, par. 1. mówiący o obowiązku zabezpieczenia przez pracodawcę życia i zdrowia pracownika. Dziękuję Annie Ciałowicz za informację o wprowadzeniu w związku z tym artykułem Kodeksu pasów zabezpieczających. 
się próby samobójcze. Szczególnie często donosi o nich prasa żydowska: dwudziestojednoletnia Chaja Monhajt, dwudziestotrzyletnia Sala Sztejnberg, dwudziestoletnia Hena Adamowska, dwudziestodwuletnia Szajndel Gutman, osiemnastoletnia Chana Miler, dwudziestodwuletnia Gołda Hartwejn ${ }^{13}$ - z ich życia pozostał jedynie ten moment, o którym niekiedy nie wiemy nawet, czy był nieszczęśliwym wypadkiem, czy bezgłośnym wyrazem ostatecznej desperacji.

Służące żydowskie podlegały podwójnemu wykluczeniu - jako służące i jako Żydówki. Domy chrześcijańskie były przed nimi zamknięte, ale i w domach żydowskich chętniej zatrudniano chrześcijanki (zob. Zalewska 1996, 248-249). „Strukturę zawodową kobiet wyznania mojżeszowego wyróżniał znacznie mniejszy odsetek pracujących jako służba domowa" (Mierzecki 2000, 115; por. też Poniat 2014, 163-166). W 1931 roku w Warszawie w służbie domowej pracowało ponad 52\% z 96 tysięcy robotnic wyznania katolickiego, w wypadku Żydówek było to nieco ponad 24\% spośród blisko 18500 zatrudnionych kobiet (Mierzecki 2000, 122) ${ }^{14}$. Etla Bomsztyk nazwie żydowskie służące „najbardziej poszkodowanymi i najbardziej prześladowanymi ze wszystkich poszkodowanych i prześladowanych" (zob. Aneks, dok. 2).

Ich los czeka na opisanie. W pierwszych dekadach dwudziestego wieku twórcy historiografii żydowskiej szczególnie silnie podkreślali potrzebę stworzenia dziejów klas podporządkowanych. Ignacy Schiper zauważał:

brak nam $[\ldots]$ historyi tych setek tysięcy, co nie $z$ ducha bogactw, ale z rąk pracy [...] snuli w przyszłość pamięć o sobie. Słowem znamy Żyda sobotniego z świąteczną duszą, czas poznać dzieje dni powszednich i myśli powszednich, czas sięgnać po światło do historii pracy żydowskiej (Schiper 1911, 1; cyt. za Kassow 2010, 65).

Uczeń Schipera, Emanuel Ringelblum, powtórzył te słowa w roku 1924, nadając im wymiar polityczny:

Jak dotąd nie ma takiego miejsca, gdzie żydowski robotnik może poznać znaczenie wiedzy historycznej dla swojej własnej walki [...]. Brakuje nam [...] wiedzy o setkach i tysiącach tych, którzy utrzymywali się nie ze swego bogactwa i intelektu, lecz z trudu

\footnotetext{
${ }^{13}$ Zob. wybór notatek prasowych przygotowany i przełożony przez Annę Ciałowicz. 2016 (5776). Kolbojnik. Biuletyn Gminy Wyznaniowej Żydowskiej w Warszawie 1 (82): 30-31.

${ }^{14}$ Podobna dysproporcję widać wyraźnie w spisie z 1882 roku, gdzie - bez podziału na płcie - zawód służącego w Warszawie wykonywało 5,7\% Żydów i 18,2\% katolików. Wyznawcy judaizmu, stanowiący 1/3 populacji aktywnych zawodowo mieszkańców miasta, pośród ogółu służących stanowili 14,5\% (Poniat 2014, 165).
} 
i znoju [...]. Znamy Żyda szabasowego, świątecznego, teraz czas poznać Żyda dnia powszedniego (cyt. za Kassow 2010, 49) ${ }^{15}$.

Historiografia winna zatem objąć wszystkie, także najniższe warstwy społeczeństwa żydowskiego. Formułując cele swych badań, Ringelblum deklarował: „zwrócę więc uwagę nie na położenie kupców, rzemieślników i innych warstw, ale na sytuację elementów zdeklasowanych, jak żebraków, próżniaków, włóczęgów...” (Ringelblum 1933, 227).

Ringelblum ponownie zacytuje Schipera w pisanym w ostatnich miesiącach życia portrecie nieżyjącego już nauczyciela (Ringelblum 1988, 545; por. Kassow 2010, 65 i 376, przyp. 24). Realizacja zadania, które Schiper postawił przed historiografią żydowska, ledwie zaczęta, pozostała niedokończona. Zginęli ci, którzy mogli napisać historię żydowskiego proletariatu i ci, dla których miała być ona napisana. Miejsce pisania historii zajął obowiązek dokumentowania Zagłady - postulaty historiografii realizowało konspiracyjne archiwum getta warszawskiego stworzone przez Ringelbluma i skupioną wokół niego grupę Oneg Szabat. W zapisanym ręką samego Ringelbluma konspekcie opracowania dotyczącego kobiety żydowskiej, które miało stanowić część planowanej przez Oneg Szabat monografii Dwa i pót roku wojny, znalazł się również punkt: „Zagadnienie służących w mieszczańskich mieszkaniach [...]. Żydowskie służące w mieszkaniu” (Bańkowska i Epsztein 2013, 137).

\section{Pamięć archiwów: biografia Etli Bomsztyk w świetle dokumentów archiwalnych}

W 1959 roku nakładem wydawnictwa Książka i Wiedza ukazał się w języku żydowskim zbiór Unter der fon fun KPP. Artiklen, zichrojnes, dokumenten („Pod sztandarem KPP. Artykuły, wspomnienia, dokumenty"). Antologia przygotowana przez Hersza Goldfingera, Michała Mirskiego i Szymona Zachariasza zawiera trzystronicowe wspomnienie Azoj iz gewen amol podpisane: E. Bomsztyk (Goldfinger, Mirski i Zachariasz 1959, 212-214). Polski przekład tego tekstu, Ongis tak było, sporządziła i opublikowała Anna Ciałowicz (Bomsztyk 2016 ${ }^{16}$ ). Bomsztyk, zaangażowana w organizowanie związków zawodowych służących domowych w Warszawie, opowiada o pierwszych latach ich działania, trudnych początkach, celach i formach walki, represjach policyjnych, wreszcie o swojej pracy partyjnej. Jej związek,

\footnotetext{
${ }^{15}$ Nie można wykluczyć, że Schiper i Ringelblum, używając przeciwstawienia „Żyda sobotniego” i „dziejów dni powszednich", podejmują tu polemikę z wpisującymi się w antysemicki stereotyp uwagami Marksa („Przypatrzmy się [...] nie temu odświętnemu Źydowi dnia sobotniego [...], lecz Żydowi dnia powszedniego"; Marks 1962, 450).

16 Zob. też: http://www.varshe.org.pl/index.php/teksty-zrodlowe/o-miejscach/221-ongi-tak-byo (dostęp: marzec 2017). Tekst jest przedrukowany w Aneksie do niniejszego artykułu jako dokument 2. Bardzo serdecznie dziękuję Annie Ciałowicz za zgodę na przedruk.
} 
początkowo sympatyzujący z Bundem, później współpracował blisko z Komunistyczną Partią Polski.

W Archiwum Akt Nowych w Warszawie znajduje się relacja Edwardy Bomsztyk poświęcona komunie więźniarek politycznych w „Serbii”, kobiecym oddziale więzienia Pawiak w Warszawie, gdzie autorka była przetrzymywana od marca do listopada 1932 roku. Relacja - w języku polskim - została nagrana na taśmę magnetofonową 14 czerwca i spisana 5 października 1966 roku (następnie zaś autoryzowana) ${ }^{17}$. Bomsztyk, pracująca w momencie aresztowania jako łączniczka między sekretariatem KPP a okręgami tej partii, opisuje życie więźniarek politycznych na Pawiaku w roku 1932, wspomina też krótko o swoich wcześniejszych pobytach w areszcie w 1926 i 1928 roku.

Wiadomości o autorce tych dwóch relacji uzupełniają dodatkowe materiały zachowane w Archiwum Akt Nowych w Warszawie:

1. Teczka osobowa Edy Bomsztyk ${ }^{18}$. Teczka zawiera tylko jedną kartę: „Wniosek na przyznanie renty dla działacza rewolucyjnego" złożony w 1953 roku.

2. Teczka Etli Bomsztyk w Centralnej Kartotece PZPR ${ }^{19}$. Teczka zawiera dokumenty z 1944 i początku 1945 roku związane ze staraniami Bomsztyk o przyjęcie do PPR: dwie wersje życiorysu z sierpnia i grudnia 1944 roku (wersja sierpniowa w rękopisie i maszynopisie, wersja grudniowa jedynie w rękopisie), dwie prośby o przyjęcie do PPR (z sierpnia i grudnia 1944), kwestionariusz partyjny wypełniony we wrześniu 1944 oraz cztery opinie popierające wniosek Bomsztyk, sporządzone przez wskazanych przez nią działaczy, którzy mogli potwierdzić jej przedwojenne zaangażowanie: Szymona Zachariasza ${ }^{20}$, Juliana (Joela) Lazebnika ${ }^{21}$, Gerszona

\footnotetext{
17 AAN, nr zespołu 1581; Zbiór relacji dotyczących ruchu robotniczego (1956-1989), sygn. R-182. Życie komuny więźniów politycznych w kobiecym więzieniu Serbia. Komuna więźniów politycznych w kobiecym więzieniu „Serbia” w Warszawie, relacja 17 - Bomsztyk Edwarda. Tekst jest publikowany po raz pierwszy w Aneksie jako dokument 3. Bardzo serdecznie dziękuję Andrzejowi Grzybowskiemu, który odnalazł ten dokument podczas kwerendy archiwalnej.
}

18 AAN, teczka osobowa 14118.

19 AAN, nr zespołu 1534; KC PZPR w Warszawie. Pion Organizacyjny. Wydział Polityki Kadrowej. Centralna Kartoteka, sygn. 289 (dawna sygn. CK/290), Bomsztyk Etla.

20 Szymon Zachariasz (1900-1970), działacz rewolucyjny, od 1916 członek partii Poalej Syjon, od 1918 w KPRP (KPP), sekretarz Centralnego Biura Żydowskiego, redaktor komunistycznych pism wydawanych w języku żydowskim, w okresie międzywojennym spędził 7 lat w więzieniach, w tym rok w obozie w Berezie Kartuskiej (1937). Od 1939 w ZSRR. W 1944 przewodniczył komisji weryfikacyjnej, która przyjmowała byłych członków KPP do PPR. Po wojnie członek Prezydium Centralnego Komitetu Żydów w Polsce i organizator Frakcji PPR przy CKŻP. W latach 1950-1956 pracował w Zakładzie Historii Partii.

${ }^{21}$ Julian (Joel) Lazebnik (1904-1981), krawiec, w latach 1923-1924 działał w dzielnicowym komitecie Związku Młodzieży Komunistycznej na Muranowie, później w komitecie warszawskim i w muranowskim komitecie KPP oraz w Centralnym Biurze Żydowskim. Walczył w wojnie obronnej Polski we wrześniu 1939, 
Staszewskiego i Eugeniusza (Enzela) Stupa ${ }^{22}$, wreszcie decyzje o „restytuowaniu w prawach członka partii”, tj. przyjęciu do PPR i zaliczeniu stażu partyjnego w KPP, podjętą w styczniu 1945 roku.

3. Wydawany przez Komendę Główną Policji Państwowej Poufny Przegląd Inwigilacyjny $^{23}$.

Wszystkie wzmianki o Edwardzie Bomsztyk rozsiane w tych dokumentach zebra1 i uporządkował Feliks Tych, przygotowując jej - ostatecznie niewykorzystany - biogram do Stownika biograficznego driałaçy polskiego ruchu robotniczego. Notatki do hasła znajduja się w Archiwum Muzeum Więzienia Pawiak ${ }^{24}$.

Etla (Edwarda, Eda, Edzia) Bomsztyk urodziła się w roku 1899 w Lipsku nad Wisłą ${ }^{25}$, była córką Sana, „czarnego robotnika”26, i Sury (Rywki) ${ }^{27}$. Materiały policyjne zawieraja jej rysopis w wieku 33 lat: „wzrostu średniego, c[iemna] szatynka, oczy brazowe”28. W 1914 roku przybyła do Warszawy, gdzie podjęła pracę służącej, którą wykonywała do roku 1930. Od roku 1918 zakładała związki zawodowe pomocy domowych i „przez długie lata była przewodnicząca Zw[iązu] Zaw[odowego] służby domowej w Warszawie"29. Z jej własnej relacji wynika, że związek działał wyłącznie w środowisku żydowskim (Aneks, dok. 2). W latach 1921-1924 należała do Bundu. W Ongis tak było pisze o swych związkach z Bundem aluzyjnie i bezosobowo: „W naszym związku większość sympatyzowała z »KomBundem«. Później związek nasz znalazł się w sferze wpływów Kompartii” (Aneks, dok. 2).

internowany na Węgrzech, uciekł do ZSRR, wstapił do Związku Patriotów Polskich, organizował repatriację z Uzbekistanu, od 1946 sekretarz generalny Centralnego Komitetu Żydów w Polsce, działacz Frakcji Żydowskiej PPR.

${ }^{22}$ Eugeniusz (Enzel) Stup (1897-1974), działacz KPZU, sądzony w procesie łuckim w 1934 roku; zob. wspomnienie w Kwartalnike Historyczny 1974, nr 4: 124.

${ }^{23}$ AAN, nr zespołu 349; Komenda Główna Policji Państwowej w Warszawie. Wydział IV. Centrala Służby Śledczej. Referat VI Specjalny, sygn. 2010-2012. Poufny Przegląd Inwigilacyjny (odtąd PPI) nr 455 z 5 października 1929, poz. 11; nr 605 z 9 lipca 1932, poz. 16; nr 677 z 14 października 1933, poz. 224; nr 709 z 12 maja 1934, poz. 137.

${ }^{24}$ Dziękuję pracownicom Archiwum Muzeum Więzienia Pawiak za udostępnienie materiałów do Stownika biograficznego dziataçy polskiego ruchu robotniçego. Kwerendę przeprowadził Andrzej Grzybowski, któremu raz jeszcze dziękuję za nieocenioną pomoc.

${ }^{25}$ Lipsko, miasto powiatowe, ob. w woj. mazowieckim, w II RP w woj. kieleckim.

${ }^{26}$ Tak w obu życiorysach z 1944 roku, AAN, nr 1534, sygn. 289, k. 1, 3, 5. „Czarny robotnik” to dosłowne tłumaczenie rosyjskiego słowa чернорабочий.

${ }^{27}$ Imię Sura pojawia się w kwestionariuszu PPR wypełnionym przez Etlę 23 września 1944 roku (AAN, nr 1534, sygn. 289, k. 9), imię Rywka - konsekwentnie w PPI.

28 PPI nr 605 z 9 lipca 1932, poz. 16; AAN, nr 349, sygn. 2010.

${ }^{29}$ Opinia J. Łazebnika, AAN, nr 1534, sygn. 289, k. 12; por. też opinia S. Zachariasza, tamże, k. 16. 
W życiorysach i kwestionariuszu, które towarzyszyły wnioskowi o przyjęcie do PPR w roku 1944, minimalizowała - z oczywistych powodów - znaczenie tego epizodu: „byłam członkiem Bundu, zwykłym członkiem”30, „w 1921 r. nieświadomie wstapiłam do Bundu, byłam zwykłym członkiem tej partii do rozłamu w końcu 1923 r."31. Po rozłamie znalazła się w Kombundzie ${ }^{32}$, a następnie w KPP, do której należała w latach 1924-1934. Współpracowała z Międzynarodową Organizacją Pomocy Rewolucjonistom, została wybrana z list komunistycznych do Rady Kasy Chorych. „Sama nieraz kierowała strajkami służby domowej w szczególnie trudnych warunkach. Pracowała również wśród kobiet"33, „w wydziale kobiecym”34. W latach 1929-1930 działała w komitecie dzielnicowym Warszawa-Muranów. W tym czasie porzuciła pracę służącej i podejmowała pracę w przemyśle papierniczym ${ }^{35}$, „przy beretach”36, ostatecznie - formalnie jako inkasentka została zawodową rewolucjonistka i od roku 1931 do aresztowania w 1932 pracowała jako opłacana przez partię łączniczka przy sekretariacie KC KPP (początkowo była łączniczką z Centralnym Biurem Żydowskim, później z organizacjami okręgowymi partii). Brała też udział w działaniach „wydziału zawodowego K[omitetu] W[arszawskiego] dla roboty wśród robotników żydowskich"37. Znamy kilka jej warszawskich adresów - wszystkie w warszawskiej Dzielnicy Północnej - „Pracowałam przeważnie na ulicy żydowskiej (muranowska dzielnica)"38: Pawia 48/65 (w roku 1928), Gęsia 29/4 (w 1932), Stawki 28 (po zwolnieniu z więzienia w 1934).

Bomsztyk pracowała jako służąca między 14 a 30 rokiem życia, zanim wyszła za mąż i urodziła dziecko. Tak też przedstawia się dominujący model zatrudnienia w służbie domowej - pracę tę wykonywały w ogromnej większości kobiety młode (zazwyczaj niemające 30 lat) i pozostające w stanie wolnym, opisywane jako life-cycle servants, tzn. osoby, dla których służba nie jest stałym, wykonywanym przez całe życie zawodem, lecz zajęciem tymczasowym,

\footnotetext{
${ }^{30}$ Kwestionariusz PPR, AAN, nr 1534, sygn. 289, k. 9.

31 Życiorys z grudnia 1944 (AAN, nr 1534, sygn. 289, k. 3), w wersji sierpniowej ta informacja została pominięta.

32 Kombund - początkowo frakcja Bundu opowiadająca się za porzuceniem stanowiska antykomunistycznego i przystapieniem do Kominternu, od 1922 roku działała krótko jako samodzielna partia, by wkrótce połączyć się z KPRP.

${ }^{33}$ Opinia J. Lazebnika.

34 Opinia E. Stupa (AAN, nr 1534, sygn. 289, k. 15), nie jest jasne, czy mowa o Centralnym Wydziale Kobiecym, czy o wydziale kobiecym Komitetu Warszawskiego KPP.

35 PPI nr 455 z 5 października 1929, poz. 11; informacja nie została potwierdzona w żadnej wersji życiorysu.

${ }^{36}$ Kwestionariusz PPR, k. 10.

37 Opinia E. Stupa.

${ }^{38}$ Życiorys z sierpnia 1944, k. 1, 5. Adresy w kolejnych numerach PPI.
} 
podejmowanym na pewnym etapie życia (przed założeniem własnego gospodarstwa domowego) i porzucanym w późniejszym okresie (Poniat 2014, 15-19 i 175-178). Należy jednak zauważyć, że w przypadku Etli Bomsztyk rezygnacja z pracy służącej wiąże się z okolicznością dla tej grupy zawodowej nietypowa - to znaczy z zaangażowaniem rewolucyjnym i niejako etatowym włączeniem się w działalność KPP. Ten polityczny wybór wiązał się z koniecznością poradzenia sobie ze szczególnie silnymi represjami policyjnymi.

O jej pierwszym, krótkotrwałym aresztowaniu w roku 1926 nie udało się znaleźć informacji innych niż te, które znajdują się w relacji nagranej w 1966 roku (Aneks, dok. 3). O dwóch pozostałych informował Poufny Przegląd Inwigilacyjny. 26 sierpnia 1928 roku Bomsztyk została aresztowana pod zarzutem przynależności do Związku Młodzieży Komunistycznej w Polsce i „udziału w akcji MDM"39. Data aresztowania Bomsztyk wskazuje wyraźnie, że celem zatrzymania było właśnie rozbicie przygotowań do obchodów Dnia Młodzieży ${ }^{40}$. Decyzją sądu śledczego dwa dni po aresztowaniu Bomsztyk została oskarżona z artykułu 102 Kodeksu karnego $^{41}$ i osadzona na Pawiaku. Zwolniono ja po dwóch miesiącach.

Do trzeciego aresztowania doszło 13 marca 1932, w ramach przeprowadzonej przez władze „likwidacji techniki K[omitetu] W[arszawskiego] KPP i KZMP, O[kręgowego] K[omitetu] Warszawy-Podmiejskiej i Biura Żydowskiego”. Zatrzymano wówczas 43 osoby ${ }^{42}$. Bomsztyk, ponownie podejrzana z artykułu 102 Kodeksu karnego, została osadzona w Areszcie Centralnym przy ul. Daniłowiczowskiej 7, po przesłuchaniu przewieziono ja na Pawiak. Tym razem doszło do procesu, w którym oskarżono ją z artykułu 97 nowego

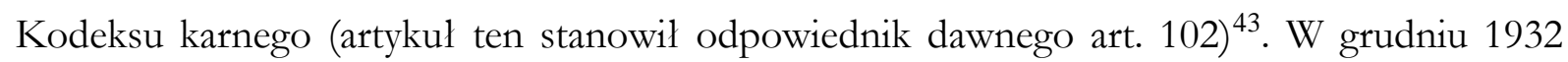

\footnotetext{
${ }^{39}$ Mowa o obchodach Międzynarodowego Dnia Młodzieży, ustanowionego na konferencji młodzieżowych organizacji socjalistycznych w Bernie w kwietniu 1915 roku. Święto miało charakter antywojenny i antymilitarystyczny (Toruńczyk 1961, 105). W II RP organizacje komunistyczne obchodziły je w pierwsza niedzielę września, socjalistyczny OMTUR zaś w pierwszą niedzielę października. O niepowodzeniu demonstracji organizowanych przez komunistów w 1925 roku mówił Tadeusz Żarski: „Były to oderwane wystapienia komunistów, które mimo bohaterstwa towarzyszy nie dawały kontaktu z masami”. 1972. IV Konferencja Komunistycznej Partii Polski. Protokoty obrad i uchwały. T. 1. Warszawa: Książka i Wiedza: 78.

40 Tak też w relacji Eleonory Stróżeckiej: „Życie komuny więźniarek politycznych więzienia »Serbia« w Warszawie”, AAN, nr 1581, sygn. R-182, k. 138, gdzie mowa o „ogromnej ogólnowarszawskiej wsypie w przeddzień święta młodzieżowego" w 1928 roku.

41 Tzn. o udział w „spisku zawiązanym dla dokonania zbrodni przewidzianej w art. 100”, tj. „zamachu na ustalony w drodze praw zasadniczych ustrój państwowy Polski albo na całość jej terytorium państwowego"; w Polsce obowiązywał wówczas zmieniony kodeks rosyjski, tzw. kodeks Tagancewa z 1903 roku.

${ }^{42}$ Teczka osobowa Andrzeja Wolicy: AAN, teczka osobowa 8463. O organizacji „techniki” KPP i represjach policyjnych zob. np. Mielczarek 1994, 84-85.

43 Tzn. „wejście w porozumienie z innymi osobami w celu dokonania przestępstwa określonego w art. 93”, tj. ,,usiłowanie pozbawienia Państwa Polskiego niepodległego bytu lub oderwania części jego obszaru”. Nowy Kodeks karny, tzw. kodeks Makarewicza, wszedł w życie w lipcu 1932 roku.
} 
roku skazano ją na dwa lata więzienia i pozbawienie praw publicznych oraz obywatelskich na pięć lat, wyrok odbywała w więzieniu w Sieradzu. Została zwolniona w maju 1934 roku.

W więzieniu poważnie zachorowała ${ }^{44}$. Po uwolnieniu zaprzestała działalności w KPP. Obok choroby mógł o tym zdecydować jeszcze jeden powód: w 1934 roku Bomsztyk wyszła za mąż za Izraela Rozmaryna, kamasznika, bezpartyjnego, choć zapewne sympatyzującego z komunizmem ${ }^{45}$. W przeznaczonych dla PPR dokumentach z roku 1944 Bomsztyk podkreśla, że mimo choroby i wystąpienia z KPP nie zerwała więzów z partią.

Wychodząc $z$ więzienia zabrałam ze sobą b[ardzo] poważne materiały dla łódzkiego MOPR-u i partii. Wychodząc z więzienia chora, nie byłam w stanie brać aktywny udział [s] w pracy partii, musiałam się ograniczyć do oddawania usługi w formie przechowania literatury, udzielenia lokalu itp. ${ }^{46}$

W roku 1935 urodziła córkę Różę. Do roku 1937 nie pracowała, bezrobotny był również jej mąż. W latach 1937-1939 utrzymywała rodzinę, gotując obiady dla działaczy partyjnych, zapewne ze wsparciem materialnym KPP.

Jesienia 1939 roku całej rodzinie udało się przedostać do Białegostoku. Bomsztyk została zatrudniona jako gospodyni partyjnego domu (,internatu”) dla przyjezdnych działaczy, Izrael pracował w kombinacie tekstylnym. Pierwszego dnia wojny niemieckoradzieckiej cała rodzina została ewakuowana przez Międzynarodową Organizację Pomocy Rewolucjonistom ${ }^{47}$. Bomsztyk $\mathrm{z}$ córką znalazły się $\mathrm{w}$ okręgu saratowskim, gdzie Etlę zatrudniono w kołchozie. Izrael Rozmaryn trafił do batalionu pracy (trudfrontu) pod Stalingradem. Po utworzeniu 1 Armii Polskiej w ZSRR (w marcu 1944) Rozmaryn walczył w jej szeregach.

W 1942 roku Bomsztyk z córka zostały przewiezione do Uzbeckiej SRR. Przez kolejne dwa lata Etla pracowała w kołchozie pod Samarkanda. Na początku 1944 roku zdołała przenieść się do Samarkandy („W 1944 r. odmówiono kołchoźnikom racji chleba, to zmuszona byłam urządzić się na pracę w mieście, żeby dostać chleb dla siebie i dziecka"48) i została zatrudniona jako szydełkarka w tamtejszej spółdzielni trykotarskiej („Wojentorgu”). Od sierpnia 1944 roku stara się o przyjęcie do PPR, co ostatecznie staje się faktem w styczniu

\footnotetext{
${ }^{44}$ Wedle opinii Zachariasza chorowała na gruźlicę.

45 Życiorys z grudnia 1944; zob. też opinia Łazebnika: „wyszła za mąż za sympatyka naszego, robotnika przem[ysłu] skórzanego", AAN, nr 1534, sygn. 289, k. 3, 13.

${ }^{46}$ Życiorys z grudnia 1944; wg. opinii Staszewskiego i Lazebnika nadal udostępniała mieszkanie na potrzeby partii; AAN, nr 1534, sygn. 289, k. 3, 13, 14.

${ }^{47}$ W latach dwudziestych Bomsztyk współpracowała z MOPR jako działaczka związku zawodowego i KPP (zob. Aneks, dok. 2).

${ }^{48}$ Kwestionariusz PPR.
} 
1945. W maju 1946 wraz z córką wróciła do Polski i osiadła w Dzierżoniowie ${ }^{49}$. Należała do PPR i PZPR. Ciężko chora na dusznicę nie mogła pracować i pozostawała pod opieką córki. Starała się o rentę i wsparcie zarówno w organizacji partyjnej PZPR, jak i w Centralnym Komitecie Żydów Polskich ${ }^{50}$. Została odznaczona Krzyżem Kawalerskim Orderu Odrodzenia Polski. Zmarła 23 września 1973 roku ${ }^{51}$, została pochowana na Cmentarzu Wojskowym na Powązkach w Warszawie.

\section{Pamięć nieoficjalna: ocalony głos Etli Bomsztyk}

Znamy zatem do pewnego stopnia biografię Edwardy Bomsztyk z okresu międzywojennego i powojennego, choć i tu konieczne i możliwe sa jeszcze uzupełnienia ${ }^{52}$. Nie wiedzieliśmy natomiast dotąd nic o jej wczesnej młodości, przypadającej na pierwsze dwie dekady dwudziestego wieku, czy też na ostatnie dekady „długiego” wieku dziewiętnastego. Tymczasem Etla Bomsztyk pozostawiła również relację z tego właśnie okresu swojego życia, autobiograficzną opowieść kończąca się na roku 1918. Jest to trzystronicowy maszynopis w języku polskim opatrzony nagłówkiem: „Dzierżoniów, dnia 18.V.1953 r.”. Tekst nie jest podpisany, nie ma też tytułu. Publikujemy go tu po raz pierwszy (Zob. Aneks, dok. 1).

Historia przetrwania tej relacji jest historią pamięci nieoficjalnej, zachowywanej i przekazywanej poza kontekstem instytucjonalnym. Maszynopis należy do niewielkiego zbioru dokumentów pozostałych po zmarłej w 2015 roku Róży (Szoszanie) Rozmaryn i przeznaczonych do wyrzucenia. Dokumenty zostały uratowane przed zniszczeniem przez Mirosława Gaszczyńskiego, dozorcę warszawskiej kamienicy przy ul. Ogrodowej, który zachował je z nadzieja, że zostaną wykorzystane w badaniach historycznych. Częścią historii tego tekstu jest wzruszenie, łzy napływające do oczu podczas lektury, niezgoda, by cierpienie tu opisane zostało zapomniane.

Ocalony przez Mirosława Gaszczyńskiego zbiór dokumentów obejmuje, poza relacja z roku 1953, skrócony odpis aktu urodzenia Róży Rozmaryn, jej dwa ręcznie pisane i niedatowane życiorysy pochodzące, jak wskazuje treść, z 1953 roku, zespół jej świadectw ze

49 Edla [s] Bomsztyk, Rózia Bomsztyk, Księga rejestracyjna repatriantów i przesiedleńców miasta Dzierżoniów; Archiwum Państwowe we Wrocławiu, Państwowy Urząd Repatriacyjny, sygn. 82/345-0-1432, s. 148. Opracowanie powojennej historii żydowskiego Dzierżoniowa przygotowuje Kamil Kijek w ramach projektu Polish Shtetl after the Holocaust? Jews in Dzierzionión, 1945-1968.

50 Zob. AŻIH 303/VIII, jedn. 148 (Archiwum Wydziału Opieki Społecznej Centralnego Komitetu Żydów w Polsce).

51 Nekrolog zamieszczony przez Komitet Warszawski i Komitet Dzielnicowy Warszawa-Wola PZPR w Trybunie Ludu nr 267 z 25 września 1973 roku.

${ }^{52}$ Niewykorzystane w tym artykule materiały biograficzne znajdują się w Rosyjskim Państwowym Archiwum Historii Społeczno-Politycznej, RGASPI, f. 495, op. 252, nr 9233. 
szkoły polskiej w Samarkandzie (lata 1945 i 1946), szkoły powszechnej stopnia podstawowego (lata 1947-1950) i licealnego (lata 1951, 1954-1955) w Dzierżoniowie, wreszcie świadectwo ukończenia szkoły muzycznej w Dzierżoniowie (klasa przygotowawcza, rok 1949). Dokumenty te pozwalają na pewną identyfikację autorki anonimowej relacji z 1953 roku.

Tekst relacji dotyczy wydarzeń sprzed roku 1918, jest więc rzeczą pewna, że nie mogła napisać go Róża Rozmaryn, urodzona - jak wiemy - w roku 1935. Odpis aktu urodzenia podaje imię matki Róży: Etla Rozmaryn z domu Bomsztyk. Informacje z życiorysów Róży Rozmaryn, w tej mierze, w jakiej dotycza jej pobytu w ZSRR w latach 1939-1945, w pełni odpowiadają znanym nam już szczegółom z życiorysów Etli Bomsztyk ${ }^{53}$. Sam tekst relacji zawiera dwie dane biograficzne potwierdzające autorstwo Etli Bomsztyk jej miejsce urodzenia: Lipsko nad Wisłą, oraz informację, że jako czternastoletnia dziewczyna w roku 1914 przybyła do Warszawy, gdzie czekało ja „zło konieczne” - praca służącej.

Dokumenty Róży Rozmaryn pozwalają nam przybliżyć kontekst powstania tego tekstu. Z serii świadectw szkolnych wynika, że w latach 1951-1953 w edukacji Róży nastapiła przerwa. Życiorysy wyjaśniaja przyczynę:

\begin{abstract}
W listop[adzie] 1951 przerwałam naukę w kl[asie] IX w szk[ole] T[owarzystwa] $\mathrm{P}$ [rzyjaciół] D[zieci], gdyż mama ciężko zachorowała. W październiku [19]52 rozpoczęłam pracę w szk[ole] TPD jako sekret[arka]. Obecnie zwalniam się z pracy, gdyż wynagr[odzenie], jakie otrzymuję, jest niewystarczające na utrzymanie siebie [i] chorej obłożnie matki.
\end{abstract}

Mamy zatem do czynienia ze wspomnieniem spisanym lub podyktowanym w okresie ciężkiej choroby.

\title{
Ciało i polityka
}

Etla Bomsztyk: kobieta, Żydówka, służąca, komunistka. Jedna z tysięcy skazanych na milczenie. Jeżeli do nas przemawia, to nie ulega waţpliwości, że właśnie komunizm dał jej głos. Zaangażowanie polityczne stanowiło treść jej życia, która mogła zostać wypowiedziana i usłyszana.

Bomsztyk zawdzięczała ruchowi komunistycznemu również fizyczne ocalenie. Przeżyła dzięki przeprowadzonej 22 czerwca 1941 roku przez MOPR ewakuacji do ZSRR.

\footnotetext{
53 Życiorysy Róży Rozmaryn uzupełniają naszą wiedzę o jeden istotny element: Izrael Rozmaryn, ojciec Róży, mąż Etli, walczył w szeregach 4 Dywizji Piechoty im. Jana Kilińskiego i poległ w walkach nad Wisłą w okolicach Warszawy w listopadzie 1944 roku. Z życiorysu pisanego przez Etlę w grudniu 1944 roku wynika, że nie wiedziała ona jeszcze wówczas o śmierci swojego męża.
} 
Zarazem ta „weteranka ruchu robotniczego”, „wielokrotnie aresztowana i więziona”, w żadnej mierze nie była uprzywilejowania. W ZSRR ciężko pracowała fizycznie, choć przecież sanacyjne więzienie i nędza ostatnich lat II RP poważnie nadwątliły jej zdrowie. Do Polski wróciła wyczerpana i chora.

Jakkolwiek większość historyków badających służbę domową w Polsce skupiała się na źródłach demograficznych, pomijając jej aktywność polityczną, działalność związkowa służących stanowiła przedmiot ważnych prac Ludwika Hassa (1963), Żanny Kormanowej (1975) i Moniki Piotrowskiej-Marchewy (2009). Największą popularnością cieszyły się katolickie (chadeckie i chrześcijańsko-narodowe) związki zawodowe, z oczywistych powodów dla Żydówek niedostępne. Natomiast „lewicowe organizacje zawodowe dominowały wśród niezbyt licznej żydowskiej służby domowej” (Piotrowska-Marchewa 2009, 208-210). Działalność związkowa podejmowały jednak tylko nieliczne spośród służących, stanowiących grupe zawodową o bardzo niskim stopniu upolitycznienia. W Ongis tak byto Bomsztyk wspomina:

\begin{abstract}
Przypominam sobie, ile wysiłku i potu kosztowało nas, grono uświadomionych pomocy domowych, stworzenie związku zawodowego. Zwołując pierwsze zebranie, pokonałyśmy niezliczoną ilość pięter. Chodziłyśmy od mieszkania do mieszkania, aż zebrałyśmy kilkadziesiąt panien służących [...]. Niewielka liczebnie była grupa osób, które wzięły na siebie trudne zadanie założenia związku zawodowego (Aneks, dok. 2).
\end{abstract}

Ostatecznie związek miał, wedle relacji, liczyć w roku 1921 około 300 członkiń, co zapewne jest liczbą zawyżona. Głos Etli Bomsztyk nie jest zatem głosem „typowym”55, co nie znaczy, że nie jest reprezentatywny (por. Ginzburg 1989, 17-18). Przy czym nie chodzi tu o jego reprezentatywność dla niewielkiej grupy aktywistek komunistycznych, lecz o ujawniające się w nim doświadczenie żydowskich warstw ludowych, uchwytne w tych fragmentach, w których opowieść Bomsztyk przekracza formy narracyjne wypracowane przez ruch komunistyczny.

Ta opowieść rodzi się bowiem na przecięciu politycznego zaangażowania, języka, który z nim przychodzi, pozwalając przemówić, i materialności, cielesności doświadczenia. W inspirującej książce poświęconej „plebejskiemu doświadczeniu politycznemu” w dobie rewolucji 1905 roku Wiktor Marzec zwraca uwage na znaczenie ,języków ideologicznych” dla „tworzenia poczucia siebie” (Marzec 2016, 200) i zauważa nie bez racji, że „uczestnictwo polityczne jest czynnikiem przekształcającym poczucie siebie w sposób, który umożliwia narrację własnego

\footnotetext{
54 Trybuna Ludu, w oryg.: ,weteran”.

55 Sam fakt, że został zapisany, czyni go wyjątkowym (por. Marzec 2016, 195). Bomsztyk jako Żydówka należy do mniejszości wśród służących, a jako komunistka - do mniejszości wśród służących żydowskich.
} 
życia i uzasadnia spisanie autobiografii" (Marzec 2016, 200-201). Zarazem jednak Marzec obstaje przy dyskursywnej naturze doświadczenia i kładzie nacisk na „politykę jego konstrukcji” (zob. Marzec 2016, 198). Ten zadziwiająco niematerialistyczny język, rodem z lat dziewięćdziesiątych dwudziestego wieku, zapoznaje znaczenie ciała - ciała głodnego, chorego, wynędzniałego, ciała pośród innych ciał, ciała, które stawia opór praktykom dyskursywnym.

W opowieści Etli Bomsztyk materialność ciała, materialność doświadczenia, jest stałym punktem odniesienia. Ten bliski związek z materialnym życiem naznacza też jej działalność związkową. Monika Piotrowska-Marchewa zwróciła uwagę, że podporządkowane KPP związki zawodowe służących koncentrowały się raczej na realizacji programu politycznego partii niż na doraźnej obronie interesów służących: „ideologia komunistyczna i ówczesna działalność rewolucyjna członkiń [związku - przyp. PL] odsuwała problemy pracy, płacy i rozrywki służby domowej na dalszy plan”, a „problemy służby domowej w o wiele mniejszym stopniu zaprzątały uwage aktywistów komunistycznych związków zawodowych" (Piotrowska-Marchewa 2009; 220, 218) ${ }^{56}$. Tymczasem Bomsztyk w Ongis tak byto podkreśla z dumą: „Udaje nam się wywalczy polepszenie warunków pracy i płacy. W pierwszym rzędzie: legalizacje związku wraz [z] zakazem zwalniania bez wiedzy związku. Dalej: trzy razy w tygodniu wolny wieczór, kasa chorych, urlop i ludzkie traktowanie”. Bo też, co nie bez znaczenia, Bomsztyk działa przede wszystkim na „żydowskiej ulicy”, współorganizowany przez nią związek początkowo nie ma afiliacji politycznej, kontakty z Bundem, potem z KPP, wreszcie przejście Etli do pracy czysto partyjnej, stanowia późniejszy etap zaangażowania - konsekwencję, nie przesłankę działalności związkowej.

Ciąła obecność materialnego doświadczenia stanowi o specyfice wspomnień Bomsztyk. Stąd rozdźwięk między ukształtowaną politycznie ramą narracyjną a perspektywą ciała, która ja rozsadza. Polityczne zaangażowanie pozwala przemówić, ale kiedy Bomsztyk zaczyna mówić, chce powiedzieć więcej.

Ów rozdźwięk ujawnia się, gdy porównać relację z roku 1953 - jedyną część wspomnień, która przetrwała poza kontekstem instytucjonalnym - z pozostałymi dwiema (przede wszystkim z Ongis tak było, które stanowi jej bezpośrednią kontynuację). Zarówno Ongiś tak było z roku 1959 (Aneks, dok. 2), jak opowieść o komunie więziennej w „Serbii”” z roku 1966 (Aneks, dok. 3) realizuja gatunkową formę „wspomnień rewolucjonistki”. W przypadku relacji więziennej wiąże się to z pewnościa z kontekstem jej powstania: mamy tu do czynienia ze wspomnieniem „wywołanym” przez Zakład Historii Partii, kształtowanym -

\footnotetext{
56 Należy jednak zauważyć, że wnioski wyciągane przez Piotrowską-Marchewę mogą być zbyt pochopne. Mówiąc o komunistycznych związkach zawodowych, odwołuje się ona bowiem w zasadzie wyłącznie do opracowania Żanny Kormanowej (1975) poświęconego jednej, specyficznej organizacji związkowej działającej na warszawskim Żoliborzu.
} 
być może także poprzez niezachowane w transkrypcie pytania - przez osobę przeprowadzającą nagranie ${ }^{57}$.

W kwestii tekstu Ongiś tak było nie wiemy, jakie były okoliczności jego powstania czy jest to po prostu dalszy ciag wspomnienia z 1953 roku spisany w tym samym czasie, później zaś wyodrębniony jako samodzielna relacja i włączony do antologii Unter der fon fun $K P P^{58}$, czy też powstał on dopiero na potrzeby książki, kilka lat po relacji z 1953 roku. W każdym razie był on $z$ pewnością opracowany przez redaktorów antologii ${ }^{59}$. Jeśli chodzi o relację z roku 1953 (Aneks, dok. 1), różną od dwóch pozostałych, nie wiemy, czy Bomsztyk planowała jej publikację, czy taką publikacje jej proponowano. Niewatpliwie i ta relacja została zredagowana ${ }^{60}$, ale możliwe, że miało to miejsce w przestrzeni prywatnej, podczas zapisywania dyktowanego tekstu. Niewykluczone, że osobą spisującą była córka Etli, Róża Rozmaryn.

Wszystkie trzy części wspomnień, choć spisane w dwóch językach, składają się na jedną całość obejmującą życie Etli Bomsztyk od wczesnej młodości do uwięzienia w 1932 roku. Relacje te powstawały po długim czasie (około 30-40 lat) i w innym świecie niż ten, o którym mówią. Jednak ten dystans, związane $z$ nim biograficzne i polityczne uwarunkowania, nie odciskają wyraźnego piętna na kształcie wspomnień, a w każdym razie nie one decydują o odmiennym charakterze pierwszej i kolejnych części.

Nie można wykluczyć, że rozdźwięk między pierwszą i pozostałymi częściami wspomnień wiąże się z ich treścią: relacja z 1953 roku dotyczy okresu młodzieńczego, doświadczeń nastoletniej dziewczyny, poprzedzających jej polityczne zaangażowanie. Jednak już sam fakt skupienia tak wielkiej uwagi na okresie wczesnej młodości oznacza wykroczenie poza formy narracyjne właściwe autobiograficznym narracjom działaczy komunistycznych.

Co zresztą istotne, ten sam rozdźwięk, który występuje między częściami wspomnień, obecny jest również wewnątrz relacji z 1953 roku. Bo też, powtórzmy, nie mamy tu do czynienia

\footnotetext{
${ }^{57}$ Charakterystyczne jest dwukrotne zastrzeżenie Bomsztyk: „Z tego okresu niewiele pamiętam”, „Co z nią teraz się dzieje - nie wiem”, a także kształt ostatniego akapitu, wyraźnie osobnego, zawierającego drobne powtórzenia.

${ }^{58} \mathrm{~W}$ takim wypadku trzeba by było postawić pytanie o język oryginału: relacja z 1953 roku jest spisana w języku polskim (ale maszynopis może być już przekładem, co wyjaśniałoby dobrą polszczyznę tekstu, por. niżej), Ongiś tak było natomiast opublikowane zostało w języku żydowskim.

59 Trudno ocenić ich wpływ na kształt tego wspomnienia. August Grabski zauważał, że Unter der fon fun $K P P$, podobnie jak inne tego typu publikacje, podlegała ograniczeniom cenzuralnym (szczególnie silnym w przypadku prac poświęconych KPP), a ponadto przygotowali ja „,ci żydowscy kapepowcy, którzy dotrwali w szeregach PZPR do chwili ukazania się tych książek dzięki całkowitej lojalności wobec partii komunistycznej na wcześniejszych stadiach jej rozwoju. Ich wartość poznawcza jest skromna” (Grabski 2004, 18, przyp. 1). Wydaje się jednak, że Ongiś tak było, tekst poświęcony w znacznej mierze działalności związku zawodowego służących domowych, nie zaś polityce partyjnej, nie stwarzał przestrzeni dla silnej ingerencji ideologicznej.

${ }^{60}$ Porównanie tekstu $z$ autografami życiorysów Etli Bomsztyk pozwala sądzić, że nie zapisywała go sama Etla. Życiorysy z roku 1944 napisane są o wiele mniej poprawną polszczyzną.
} 
z prostym przeciwstawieniem dwóch typów narracji, lecz ze splotem praktyk dyskursywnych właściwych ruchowi komunistycznemu i materialności doświadczenia, które domaga się artykulacji. Zarazem jednak w relacji z 1953 roku kontrast między pierwszym akapitem a dalszym ciagiem tekstu jest tak silny, że nie sposób się oprzeć wrażeniu, iż ów otwierający fragment został do tej relacji dopisany, dodany - mówi on zreszta o okresie międzywojennym, podczas gdy cała relacja dotyczy losów Bomsztyk sprzed 1918 roku.

„Pamiętam Polskę - tę sprzed września, bogatą w przepych i nędzę największą, kraj panów i sług...” - zaczyna swą opowieść Bomsztyk i w syntetycznym skrócie daje obraz położenia służących w pierwszych latach II RP. Ten akapit jest zbieżny z wprowadzeniem do Ongis tak byto ${ }^{61}$. W obu wypadkach mamy do czynienia $z$ narracją trzecioosobowa, zobiektywizowaną, pozbawioną odniesień do własnych doświadczeń, a zatem typowa dla autobiografii robotników zaangażowanych w działania partii politycznych. Jak zauważa Wiktor Marzec:

wiele relacji jest konstruowanych tak, by wygasić własną podmiotowość, ukazać raczej zobiektywizowany obraz bezosobowego działania dla sprawy, w którym jest się tylko elementem. Brakuje szczegółów biograficznych, motywacji, stanów emocjonalnych. Narracja w pierwszej osobie jest pewną fikcją gramatyczną bardzo często ustępuje miejsca zobiektywizowanemu głosowi relacjonującemu podejmowane przez partie działania (Marzec 2016, 203).

O ile jednak w Ongis tak było opis warunków pracy służby domowej stanowi punkt wyjścia dla prowadzonej w pierwszej osobie liczby mnogiej opowieści o aktywności związkowej i partyjnej, we wspomnieniu z roku 1953 ogólne uwagi o sytuacji służących rozwijają się w przejmująca, intymną retrospekcję. Zmienia się też forma opowieści - zdanie: „Jedną z nich byłam ja" wprowadza zupełnie nową perspektywę, narracja prowadzona jest odtąd w pierwszej osobie liczby pojedynczej i skupia się na osobistym doświadczeniu głodu, chorób, nędzy, która „wygania z domu”, samotności czternastoletniej dziewczyny oddanej na służbę w obcym mieście i zmuszonej do pracy ponad siły.

Wspomnienie z roku 1953 wykazuje zbieżność raczej z literaturą tworzoną w języku żydowskim niż z partyjna narracją autobiograficzna. Nie oznacza to, że Bomsztyk przejęła formy narracyjne znane jej z lektur (choć nie jest to też całkowicie wykluczone), lecz raczej że

\footnotetext{
61 Ongiś tak było (Aneks, dok. 2): „Życie dziesiątek tysięcy biednych żydowskich dziewcząt w dawnej Polsce przedstawiało obraz nędzy i rozpaczy: wygnane przez panującą na wsi i w sztetlu biedę, wyruszały w świat za kawałkiem chleba”; relacja z 1953 roku (Aneks, dok. 1): „Nieopisanie ciężki był los tych dziewcząt, które nędza wygnała z domu, ze wsi i miasteczek. W mieście, nie mając dachu nad głową [...] zmuszone były iść na ten niewolniczy kawałek chleba”.
} 
literatura - „literatura mniejsza” (Deleuze i Guattari 201762) - zdołała lepiej niż język politycznego aktywizmu uchwycić doświadczenia klas podporządkowanych. Bomsztyk potrafi tworzyć obrazy o niezwykłej intensywności osiaganej dzięki samej tylko precyzji opisu skupia się na konkretnych sytuacjach, na własnym doświadczeniu i własnych obserwacjach. Sposób, w jaki Bomsztyk opisuje ojca, może kojarzyć się z jednym z najszerzej czytanych opowiadań literatury w języku żydowskim - tekstem Icchoka Lejbusza Pereca Bońcie Milczek:

Tu, na tym świecie, śmierć jego nie wywarła żadnego wrażenia. Zapytajcie kogoś pod groźbą wyklęcia - i tak nie odpowie, kim był Bońcie Milczek, jak żył i z jakiej przyczyny zmarł. Nikt nie jest w stanie odpowiedzieć. Czy serce mu pękło, czy siły go opuściły, czy kręgosłup złamał się pod ciężkim ładunkiem... Kto wie? A może zmarł z głodu.

Gdyby padł koń tramwajowy, interesowałoby to każdego o wiele więcej. Pisano by o tym w gazetach, setki ludzi $z$ różnych ulic spieszyłyby obejrzeć padlinę [...]. Przypuszczalnie koń tramwajowy nie dostapiłby również takiego zaszczytu, gdyby koni było tysiąc milionów - tyle co ludzi (Perec 1958, 157).

Bomsztyk zaś mówi:

\begin{abstract}
Na swą ciężką pracę nigdy się nie skarżył [...]. Nieraz sekretarz gminy posyłał ojca do $\mathrm{m}$ [iasta] pow[iatowego] Iłży z pismem. Taki posłaniec wynosił taniej niż koń, któremu oprócz pokarmu trzeba dać furmana. Ojciec wychodził o świcie, zabierał w kieszeni kawałek suchego chleba, który mama brała na borg na konto tego zarobku. Wracał na drugi dzień śmiertelnie znużony... (Aneks, dok. 1).
\end{abstract}

Ani w Ongiś tak byto, ani w relacji więziennej Bomsztyk nie poświęca uwagi swojej rodzinie. W jej życiorysach z roku 1944 ojciec zostaje jedynie wspomniany jako - jak widzieliśmy „czarny robotnik”. W relacji z roku 1953 opisuje szerzej, jak najmuje się „do każdej natrafionej roboty”. Uwage zwraca przede wszystkim stwierdzenie, że ojciec „zawodu nie miał żadnego, gdyż rodzice jego uważali, że szewc lub krawiec poniża godność rodziny. Mówiło się wówczas: szewcy, krawcy - to nie ludzie" (Aneks, dok. 1). Można zatem przypuszczać, że Etla pochodziła z rodziny gwałtownie zubożałej w pokoleniu jej rodziców. Zarazem zastanawia fakt, że „ojciec był stuprocentowym analfabetą, skoro dziadek Etli był jeszcze w stanie płacić za czteroletnią edukacje jej starszego brata.

\footnotetext{
${ }^{62}$ Zob. zwłaszcza rozdz. 3.
} 
Istotnym elementem opowieści z 1953 roku jest nacisk, z jakim Bomsztyk nazywa służące „robotnicami”"63. Tu ujawnia się wpływ jej politycznego zaangażowania. Termin „robotnica domowa” sam w sobie emancypuje, przekształca niewolnice w proletariat, pozwala zyskać kolektywna podmiotowośćc4 i rozpoznać swoje położenie w kategoriach społeczno-ekonomicznych. W pierwszym akapicie Bomsztyk pisze:

Codzienny trud robotnika wzbogacał panów, lecz by codziennie używać, rozkoszować się tym bogactwem, burżuazja zatrudniała innego rodzaju robotnika, który był bezpośrednim wykonawcą wszystkich jej kaprysów i zachcianek. Tym wykonawca była niezliczona masa robotnic domowych - służba domowa (Aneks, dok. 1).

I mimo rozdźwięku między tym wprowadzającym fragmentem a dalszą częścią tekstu sam termin „robotnica domowa” będzie stosowany konsekwentnie. W Ongis tak byto Bomsztyk przedstawia już narrację typową dla autobiografii zaangażowanych politycznie robotników. Koncentruje się więc na agitacji związkowej, manifestacjach, plakatowaniu, kolportażu nielegalnej prasy i literatury. Emancypacja dokonuje się przez zaangażowanie w działalność partyjna $^{65}$ : „Takie one były, te pomoce domowe - najbardziej poszkodowane i najbardziej prześladowane ze wszystkich poszkodowanych i prześladowanych. Dopiero Kompartia wprowadziła je do szeregów walczącego proletariatu i uczyniła z nich to, co opisałam powyżej: bojowniczki” (Aneks, dok. 2).

Działalność związkowa i partyjna pozwala przełamać fatalizm upodlonej egzystencji, daje siłę do przetrwania - nawet w więzieniu. We wspomnieniu z roku 1966 Bomsztyk kładzie nacisk na podejmowane przez komunę więźniarek działania oporowe, demonstracje i protesty, bo też alternatywa jest jasno rozpoznana: „protestujemy przeciwko przemocy, albo ustępujemy wobec przemocy" (Aneks, dok. 3). Stąd też wyraźnie zaznaczone w relacji z „Serbii” rozróżnienie między aresztowanymi komunistkami a „ofiarami”, osobami przypadkowo zatrzymanymi, niezaangażowanymi w działalność rewolucyjna.

Ale też właśnie w dokumentach odnoszących się do okresu więzienia najsilniej widoczny jest dyscyplinujacy i w istocie bezwzględny wymiar partyjnej kultury walki. Nie ma

\footnotetext{
${ }^{63}$ Tego samego terminu Bomsztyk używa w obu życiorysach z 1944 roku.

64 Zauważmy na marginesie, że Lew Trocki, analizując reakcyjny charakter stalinowskiego „termidora”, twierdził, że w warunkach radzieckich termin „,robotnica domowa” jest jedynie „socjalistyczną etykietką” zakrywająca społeczne kontrasty w ZSRR. „Spośród 40 milionów rodzin, tworzących ludność Związku Radzieckiego, $5 \%$ a może $10 \%$ buduje swoje »ognisko« pośrednio lub wprost na pracy domowych niewolnic i niewolników. Dokładna liczba radzieckich służących miałaby dla socjalistycznej oceny sytuacji kobiety w ZSRR nie mniejsze znaczenie niż całe radzieckie ustawodawstwo, jakkolwiek byłoby ono postępowe. Właśnie dlatego jednak statystyka kryje służące w rubryce robotnic..." (Trocki 1991, 119).

65 Por. Marzec 2016, 27 („Materiały biograficzne zaświadczają o zmianie na poziomie osobowym [...]. Potwierdzaja znaczenie aktywizacji politycznej w konstrukcji siebie”).
} 
tu miejsca na słabość: „brałam aktywny udział w kierownictwie partyjnym komuny mimo tego, że przez cały czas pobytu w więzieniu ciężko chorowałam"66. Życiorysy pisane w 1944 roku naznaczone są - gdy mowa o zaprzestaniu pracy partyjnej po wyjściu z więzienia tonem skruchy: „Przez cały czas siedzenia w więzieniu chorowałam silnie $\mathrm{i}$ to mnie uniemożliwiło po wyjściu $z$ więzienia pracować aktywnie w partii. Nato[miast] współpracowałam i pomagałam, czem tylko mogłam" ${ }^{67}$. Szczególną odpornością trzeba wykazać się w śledztwie i na procesie - to rzecz powszechna w kulturze organizacji rewolucyjnych, nie tylko zreszta nowoczesnych ${ }^{68}$. W przypadku KPP, zatruwanej mniej lub bardziej uzasadniona paranoja, gdy idzie o przenikających w jej szeregi policyjnych agentów, a w roku 1938 rozgromionej przez Stalina właśnie z powodu jej rzekomego zinfiltrowania, zachowanie podczas procesu podlegało rozbudowanej kontroli i bezlitosnej ocenie. Nie jest przypadkiem, że ten wątek pojawia się w niemal wszystkich dokumentach związanych z wstapieniem Bomsztyk do PPR. Wyjątkiem jest życiorys z sierpnia 1944, ale już w wersji grudniowej Bomsztyk pisze: „na rozprawie i w więzieniu zachowywałam się jak oddany komunista”. W kwestionariuszu PPR znajduje się osobne pytanie: „Jak zachowywał się przy aresztowaniu, na rozprawie, w więzieniu i obozie?”. Bomsztyk ponownie deklaruje: „przy każdym aresztowaniu, na rozprawie i w więzieniu zachowałam [się] jak uczciwy komunista”. Kwestia ta wraca w wystawionych jej opiniach: „W śledztwie, w więzieniu, jak również na rozprawie sądowej zachowała się godnie stanowiska rewolucjonisty”69, „Wiem również, iż w latach 1932-34 siedziała w więzieniu, przy tem żadnych zarzutów w stosunku do niej nie słyszałem"70, „Wiem, iż tow. Bomsztyk zachowywała się dobrze tak w więzieniu, jak i w sądzie" "71. Jest coś trującego w tym inkwizytorskim tonie.

Aktywistyczna narracja komunizmu daje więc siłę, wyzwala, ale i dyscyplinuje. I spycha w milczenie to wszystko, co słabe, nieheroiczne, prywatne. W relacji z 1953 roku widzimy Bomsztyk jako dziewczynę słabą i chorowita: czarna ospa w wieku lat 9, grypa hiszpanka dziesięć lat później - „tak rosłam mizerna, słaba i apatyczna”, powiada o swoim dzieciństwie i kreśli autoportret z czasów, gdy miała lat 14: „byłam wstydliwa, zawsze smutna, głowę trzymałam nisko schyloną" (Aneks, dok. 1). Dwie pozostałe relacje przedstawiaja osobę dzielna, aktywna, energiczna, zaangażowaną $w$ pracę związkowa i partyjną:

66 Życiorys z grudnia 1944, k. 3.

67 Życiorys z sierpnia 1944, k. 1, 5.

68 Por. uwagi Ewy Wipszyckiej o późnoantycznych „upadłych” (lapsi) chrześcijanach, którzy w obliczu prześladowań zaparli się wiary, i o wynikłej stąd kontrowersji między „rygorystami” a „oportunistami”. Wipszycka zauważa, że jakkolwiek „upadłych” „było na pewno bardzo wielu”, „historycy katoliccy niechętnie piszą o lapsi, psują im oni obraz heroicznego Kościoła” (Wipszycka 1994, 118-123, cytaty: 119 i 118).

69 Opinia Lazebnika, k. 13.

70 Opinia Staszewskiego, k. 14.

${ }^{71}$ Opinia Stupa, k. 15. 
organizatorkę, działaczkę, twardą nawet w więzieniu. Jeśli wspomnienie z roku 1953 stanowiło całość z Ongiś tak było, nie jest wykluczone, że mamy tu do czynienia ze świadomym skontrastowaniem młodzieńczej słabości, niezdolności do oporu wobec potwornej nędzy, z siła, którą daje zaangażowanie i polityczne „wyrobienie”. Użycie terminu „robotnica domowa” stanowiłoby antycypacje przemiany słabej, chorowitej dziewczynki w silną aktywistkę. Niewatpliwie wspomnienie z roku 1953 jest historią przezwyciężania słabości - ale Bomsztyk przedstawia tę historię jako samotne zmaganie się z rzeczywistością:

Nie mogłam już nawet jeść z powodu tęsknoty i wyczerpania. Gdy brat, któremu o tym z płaczem opowiedziałam, zaproponował mi powrót do domu - odpowiedziałam stanowczo, że muszę się przyzwyczaić i tak wyrobić, by pomóc rodzinie, a jeśli nie potrafię tego przewalczyć, wolę umrzeć, a do poprzedniej nędzy nie wrócę (Aneks, dok. 1).

Każdy kolejny cios czyni Etlę twardszą, lecz zaangażowanie w komunizm nie odgrywa w tej transformacji żadnej roli, przychodzi później. To nie Kompartia czyni z Bomsztyk bojowniczkę, to bojowniczka wstapi do Kompartii.

Jeśli więc relacja z roku 1953 zbudowana jest na przeciwstawieniu bierności i działania, to jego artykulacja nie ma nic wspólnego z organizującą wspomnienie z roku 1966 opozycja „ofiary” i „partyjniaczki”. Jedynym zewnętrznym punktem odniesienia są biegunowo różne postacie matki i brata. Matka to uosobienie bezradnego cierpienia bezzębna, doświadczająca wciąż głodu i poniżenia, które przyjmuje jako los. Jest w tej opowieści głośno wypowiedziana złość: „,czuliśmy żal do matki, że nas tyle miała, a nie mogła dać nawet chleba. Wówczas odpowiadała nam, iż pan bóg daje dzieci, więc ich nakarmi. Trzeba go tylko o to prosić i czekać cierpliwie, aż prośbę usłyszy. Tak pocieszała nasze zgłodniałe żołądki” (Aneks, dok.1). Ale ów gniew szybko ustępuje tkliwej litości i tęsknocie.

$\mathrm{Na}$ drugim biegunie jest brat, podziwiany i obdarzany najintensywniejszym uczuciem. Nie sposób nie zauważyć, że Etla powtarza jego drogę życiową. W istocie ich postacie jawia nam się jako sobowtórowe: obydwoje wyjeżdżaja do Warszawy, gdzie ciężko pracują, żyjąc w skrajnym ubóstwie u obcych ludzi; obydwoje porzucają religię i podejmuja samodzielne poszukiwania intelektualne; wreszcie obydwoje wstapia do partii komunistycznej. Etla jest przy tym zawsze krok za bratem.

Z osobą brata wiąże się niezwykle istotny element relacji z 1953 roku antymilitaryzm. „Radość trwała krótko, ponieważ był w wieku poborowym - wzięto go do wojska. Było mu bardzo źle, pisał smutne listy" (Aneks, dok. 1). To rok 1912, jeszcze czas pokoju. Wojna przynosi bezkresne cierpienie:

nadeszło zło przekraczające dotychczasowe. Nadszedł 1 sierpień. Wybuchła 1-sza wojna światowa. Powszechna mobilizacja zabiera drogiego mi brata [...]. Całe dnie 
spędzam na punkcie zbornym przy ulicy Pokornej, która roi się od ludzi. Płaczę, rozpaczam razem z rodzinami żegnającymi braci, ojców, mężów (Aneks, dok. 1).

Bomsztyk nie interesuje ani wojenna mitologia produkowana obficie przez aparaty ideologiczne ${ }^{72}$, ani polityczna krytyka tej mitologii - w jej opowieści liczy się tylko najbardziej materialne doświadczenie: tłum nieszczęśliwych ludzi ${ }^{73}$. Wojna prowadzi bliskich na zatracenie, przynosi powszechną pauperyzację, rosnące bezrobocie, całonocne kolejki po chleb, wreszcie - deportacje. Lipsko zostaje spalone przez wycofujące się wojsko rosyjskie, rodzice Etli wraz z trójką dzieci uciekaja do Warszawy, gdzie tułaja się po ulicach „w pogoni za wodnistą zupką filantropijnych kuchen”. Bomsztyk, mieszkająca u zatrudniającej ją rodziny, zapewnia im schronienie na noc: „wieczorem, gdy gospodarze kładli się już spać, wpuszczałam ich po kryjomu do kuchni, gdzie spali kilka godzin na samej podłodze. W obawie przed chlebodawcami budziłam ich przed świtem i z bólem w sercu wyganiałam na ulicę" (Aneks, dok. 1).

Los rodziców Etli Bomsztyk jest losem całych społeczności żydowskich wygnanych z miasteczek leżących przy linii frontu. Do Warszawy przybywają fale uchodźców. Ponownie to literaturze udaje się uchwycić perspektywę warstw ludowych. Szalom Asz w tekście Warsqawa 1914 pisal:

Ulicami Warszawy ciagną smutne szeregi ludzi. Manifestacja wojny. Idą Żydzi w oberwanych ubraniach, w szabatowych krymkach na głowach, a na plecach i w rękach niosą pakunki: znajome tobołki z pościelą zawiniętą w prześcieradło [...]. Aleje Jerozolimskie, szeroka, piękna ulica, gdzie mieszka warszawska arystokracja, były ożywione, gdy ta smutna procesja weszła z szosy skierniewickiej. Cała szlachta z okolicznych prowincji zjechała na czas wojny do Warszawy i mieszkała w prominentnej części miasta [...]. Szerokimi trotuarami przechadzały się smukłe polskie damy i panienki, które $\mathrm{w}$ czasie wojny nie zapominały o figurze i wysmakowanych toaletach. Zobaczywszy smutną procesję brudnych Żydów, umorusanych bab i rozwrzeszczanych żydowskich dzieci, mówiły jedna do drugiej:

72 Nie ulega wątpliwości, że właśnie antywojenny program Lenina stanowił klucz do sukcesu partii bolszewickiej w 1917 roku. Los brata Etli, wcielonego do wojska u progu wojny, walczącego „na różnych frontach”, by w roku 1918 przystać do bolszewików, jest tu tyleż typowy, co znaczący. Osobnym problemem pozostaje natomiast dokonująca się równolegle w wielu planach i pod wpływem wielu czynników „militaryzacja” rewolucji.

${ }^{73}$ Zajmującym przykładem subwersywnej mocy ludowej pamięci o wojnie jest historia wykonania pieśni O Gorizia, tu sei maledetta („Gorizio, bądź przeklęta”) na festiwalu w Spoleto w 1964 roku. Pieśń, opowiadająca o jednej z bitew Wielkiej Wojny, stanowiła część spektaklu Bella Ciao. Wykonujący ją Michele Straniero wywołał skandal, śpiewając fragment znany mu z tradycji ludowej, lecz nieobecny w oficjalnej wersji tekstu: „traditori signori ufficiali / che la guerra l'avete voluta / scannatori di carne venduta / e rovina della gioventù..." (,zdradzieccy panowie oficerowie, którzy chcieliście wojny, rzeźnicy, sprzedawcy mięsa, niszczyciele młodzieży”). 
- Żydzi zalewają Warszawę, ta wojna będzie nas kosztowała jeszcze pięćdziesiąt tysięcy Żydów, którzy zamieszkają w stolicy i będą nam zatruwać powietrze jak myszy w spichlerzu (Asz 2017).

Najistotniejszym wątkiem wspomnień Etli Bomsztyk, jeśli chcemy rozpatrywać je w kontekście rozdźwięku między osobistym doświadczeniem a narracją partyjną jest historia intelektualnego dojrzewania. Bomsztyk wielokrotnie powtarza, że „nie widziała nigdy szkoły”, a tylko brat „nauczył ją abecadła, reszty uczyło [ich - zm. PL] życie” (Aneks, dok. 1). W 1944 roku, w kwestionariuszu PPR, w rubryce „wykształcenie ogólne” napisze: „domowe”, w rubryce „wykształcenie partyjne” zaś poda: „ogólnikowe”. Głód wiedzy jest dojmujący, to element stale obecny w robotniczych autobiografiach, Bomsztyk chwyta się więc każdej szansy: „Bardzo chciałam się uczyć i w tym celu przypochlebiałam się dzieciom chlebodawcy, mając nadzieję, że podzielą się trochę swą wiedzą. Osiemnastoletnia córka gospodarzy czasem późno wieczorem uczyła mnie trochę rachunków i niemieckiego" (Aneks, dok. 1) $)^{74}$.

Relacja więzienna z 1966 roku ujawnia, jak wielkie znaczenie dla procesu nabywania i wymiany wiedzy miało zaangażowanie polityczne. Już samo „ogólnikowe” wykształcenie partyjne pozwalało nawiązać kontakt z zaangażowanymi inteligentkami i dodawało pewności siebie. Wspólny więzienny los wzmacniał relacje i stwarzał okazję do pogłębionej nauki. Wspominając pobyt na „Serbii”, Bomsztyk pisze o współwięźniarkach, Zofii Dorosz i Marii Hering, towarzyszkach z KPP: „Ja byłam robotnica, miałam tylko doświadczenie z pracy partyjnej, ale nie miałam wykształcenia. One starały się nauczyć mnie wszystkiego, co tylko mogły" (Aneks, dok. 3). Co istotne, w polu wyznaczonym przez polityczny aktywizm uczennica może szybko stać się nauczycielką ${ }^{75}$ : „do mojej celi dano [...] jedną bezpartyjna, tzw. ofiarę. Starałam się przekazać tej bezpartyjnej wszystko, co zdobyłam dzięki Marii i Zofii. Partyjnie byłam dobrze wyrobiona i postanowiłam sobie za cel wychować tę »ofiarę« na dobra partyjniaczkę. Z przyjemnością stwierdziłam później, że to mi się udało" (Aneks, dok. 3).

Historia edukowania „ofiary” wskazuje jednak wyraźnie, że jakkolwiek wiedza, którą Etla nabyła od Zofii i Marii, wykraczała poza jej wcześniejsze „doświadczenie z pracy partyjnej”, to ostatecznie pozostawała funkcjonalna w ramach politycznego zaangażowania,

74 Warto zwrócić uwagę na dystans, z jakim Bomsztyk pisze o ówczesnym zaangażowaniu swojej nastoletniej nauczycielki w działalność socjalistyczną. Widać wyraźnie, że aktywność polityczna, wymagająca, jak czytamy, zdecydowanego przeciwstawienia się rodzinie, nie przekładała się w najmniejszym stopniu na przełamanie barier dzielących „mieszczańską część młodzieży szkolnej” od mieszkającej pod tym samym dachem służby.

75 O tej specyficznej pozycji już „nie odbiorców wiedzy, ale też nie przekazujących ją inteligentów” zob. Marzec 2016, 207. 
wzmacniała je i pogłębiała. Tymczasem w relacji z 1953 roku otwiera się przestrzeń wielowątkowej, otwartej działalności intelektualnej - kultury, która jest radością i wytchnieniem:

\begin{abstract}
Najradośniejsze w życiu rodziny były chwile spędzane z bratem, gdy przyjeżdżał do domu na święta. Opowiadał o Warszawie, o kinie, w którym był zaledwie raz w ciagu roku. Śpiewał nam piosenki zasłyszane na warszawskich podwórkach [...]. Był jakby promieniem słonecznym w naszym ponurym życiu. Później przywoził książeczki, które czytałam rodzeństwu. Zapominaliśmy przy tym o głodzie i innych dolegliwościach. Uczyłam młodszych braci abecadła. Wkrótce byliśmy wszyscy jednakowo uczeni (Aneks, dok. 1).
\end{abstract}

Nie wiemy, czy i w jakim stopniu przywożone przez brata lektury miały charakter polityczny. Wiemy, że w tym czasie zarabiał korepetycjami, że w roku 1918 wstapił do partii bolszewickiej i zginął w wojnie domowej. Czy był zaangażowany w działalność rewolucyjna jeszcze przed rokiem 1912?

\begin{abstract}
Przywoził również gazety. Czytał na głos. Wiele ludzi przychodziło posłuchać. Tłumaczył, opowiadał, lecz ja nic z tego nie zrozumiałam. W miasteczku mówiono, że jest filozofem i bezbożnikiem. Rodzice, chociaż byli bardzo pobożni, jakoś nie przejęli się tym. Przeciwnie, stał się chlubą naszej rodziny. Pragnęliśmy mu wszyscy dorównać (Aneks, dok. 1).
\end{abstract}

Etla miała wówczas nie więcej niż 12 lat. Opowieści brata są w jej biografii intelektualnej poczatkiem drogi, pierwszym impulsem. Przełomem jest natomiast jego śmierć - i choć zginął jako bolszewik w walkach w rewolucyjnej Rosji, wydaje się, że w roku 1918 dla Etli ten polityczny kontekst nie ma jeszcze znaczenia:

\begin{abstract}
Tak płynęło moje życie w udręce, cierpieniach, bez słońca i radości, w wyniku czego przestałam wierzyć w boga, zaniechałam modlitwy, gdy przekonałam się, że w życiu moim nie ma poprawy, a zło nie ma końca, że muszę sama walczyć o swój byt. Wielkie było moje rozczarowanie w to, co czytałam w modlitewniku i w to, co opowiadała mama. Zaczęłam filozofować, rozmyślać, szukać odpowiedzi na dręczące mnie kwestie (Aneks, dok. 1).
\end{abstract}

Potrzeba filozofowania rodzi się z cierpienia, z samotności, z koszmaru wojny i z bolesnej straty. Jeszcze nie czas na polityczne zaangażowanie. Działalność związkowa, akces do Bundu, do ruchu komunistycznego, przyjdą później. Teraz jest czas samodzielnych poszukiwań, intelektualnego niepokoju, dość chaotycznie zdobywanych lektur. Wedle Wiktora Marca „Niezwykle mało jest samorodnych autodydaktów straceńczym uporem 
wydobywających się ze swojej sytuacji [...], czy przejawów oddolnej proletariackiej kultury niezwiązanej z aktywizacja polityczną" (Marzec 2016, 217). Czy jednak to wrażenie nie jest raczej skutkiem „milczenia archiwów”? W przypadku Etli Bomsztyk filozofowanie nie potrzebuje teorii politycznej przychodzącej z zewnątrz, by je pobudzić i ukształtować, ale też nie zamyka się szczelnie w kręgu tego, co dane i już znane. Nie jest ani poddaniem się ideowej kolonizacji, ani otorbieniem się w skansenie własnej tożsamości, lecz swobodnym tworzeniem, które wyrywa się w świat, by poznać i przywłaszczyć sobie teksty oraz myśli dotąd niespotkane (por. Rancière 1981, Ginzburg 1989) ${ }^{76}$. Bomsztyk żywi się lekturami przypadkowymi, tekstami z każdego rejestru kultury. „Poczęłam czytać książki, które popadły [s]. Potem zapisałam się do czytelni przy ul. Mariańskiej. Gdy szłam po zakupy, wkradałam się do czytelni po książki, które czytałam po kryjomu w nocy, bo co to za służąca, co czyta książki? Czytałam chaotycznie, Tołstoja i Bocaci'ego Hermalina itd. [pisownia org. - PL]" (Aneks, dok. 1).

Jest rzeczą uderzająca, że w relacji zapisanej 35 lat później wyróżnione miejsce zajmuja teksty Dawida Mojsze Hermalina (1865-1921). Ten niezwykle płodny autor pochodził z Rumunii, w wieku 20 lat przybył do Nowego Jorku, gdzie pracował jako dziennikarz prasy wydawanej w języku żydowskim. Pisał powieści i popularne dziełka filozoficzne (o szerokim zakresie tematycznym, obejmującym hipnotyzm, wolną miłość, astronomię, biografię Jezusa i Mahometa), ale zasłynął przede wszystkim jako autor bardzo swobodnych przekładów klasycznych dzieł literatury europejskiej na język żydowski. W istocie mamy tu do czynienia $z$ autorskimi tekstami Hermalina pisanymi na kanwie „przekładanych” dzieł. Wśród autorów, po których sięgał, są Goethe, Zola, Maupassant, Swift, Szekspir, wreszcie - czytani przez Bomsztyk - Tołstoj i Boccaccio. Przetwarzając teksty właśnie tych dwóch autorów, Hermalin opierał się na tłumaczeniach (nie znał rosyjskiego ani włoskiego). Spośród pism Tołstoja zaadaptował Bajkę o głupim Iwanie i jego dwóch braciach (Iwan der nar), Anne Karenine (Ana Karenina), Sonate kreutzerowska (Di krojcer sonata) i Spowied乏́ (Majn widoj: a filozofisze berachung iber lebn, religion un got). Przełożył również biografię Tołstoja autorstwa Wilhelma Henckla (Tolstojs biografie).

Z dzieł Boccaccia Hermalin opublikował wybrane nowele z Dekameronu, swobodnie zmieniając tytuly i znacznie rozbudowując tekst. W Hebrew Publishing House w Nowym Jorku ukazały się cztery tomiki jego „przekładów”: Paskarela, Madam Babeta, Di cwej poorlach

\footnotetext{
${ }^{76}$ Marzec odrzuca rzecz jasna perspektywę Rancière’a, uznając ją za nieprzydatną dla badań ziem polskich, różnych od Francji z jej „długoletnią tradycją robotniczą”: „w źródłach biograficznych, wydźwignięcie, kompletnie przeobrażające polityczny [...] świat Królestwa Polskiego występuje, ale jest nieodłącznie związane z aktywizmem partyjnym i różnorodną działalnością środowisk politycznych [...], homologiczną rolę wobec proletariackiej kultury u robotników francuskich badanych przez Rancière’a pełniła w Królestwie Polskim aktywizacja polityczna" (Marzec 2016, 217-218). Zauważmy tylko, że wbrew temu, co zdaje się twierdzić Marzec, tradycja robotnicza raczej czerpie z kultury i pamięci warstw podporządkowanych świata przedindustrialnego, niż z nimi zrywa.
} 
(„Dwie pary”, 1912), Princesin Culejka („Księżniczka Zulejka”). Dwa pierwsze wydano później w języku angielskim jako Pasquerella and Madonna Babetta (Biblion Society, New York 1927). Książka była niewiarygodnym humbugiem. Przełożone dziełka Hermalina - Paskarela nie miała nic wspólnego z Boccacciem, poza tym, że Hermalin (zapewne dla lepszej sprzedawalności) podpisał jego nazwiskiem swój własny utwór; Madam Babeta zaś stanowiła bardzo luźne przetworzenie noweli Spowiedź (Dekameron III, 3) - reklamowano jako pierwsze angielskie wydanie dwóch dotąd nietłumaczonych nowel Boccaccia, ozdobione na dodatek niepublikowanymi rysunkami Aubreya Beardsleya. Rzecz jasna Beardsley miał z tą publikacja równie wiele wspólnego co Boccaccio.

Dwa pozostałe wydawnictwa Hermalina maja nieco ściślejszy związek z dziełem Boccaccia. Di cwej poorlach stanowią swobodną adaptację noweli Rogi za rogi (Dekameron VIII, 8), Princesin culejka zaś to adaptacja noweli Alatiel, narzeczona króla Algarbii (Dekameron, II, 7). W przypadku tej ostatniej noweli, opowiadającej o córce sułtana, która wzbudza nieposkromioną żądzę kolejnych porywających ją mężczyzn, Hermalin zmienił imię bohaterki na „Zulejka” - w apokryficznej tradycji żydowskiej i muzułmańskiej imię to nosiła zakochana w Józefie żona Potifara.

Niestety nie wiemy, które z tych książek czytała nastoletnia Etla, a przede wszystkim nie możemy odpowiedzieć na ginzburgowskie pytanie, jak je czytała. Być może dla wytchnienia, by zapomnieć o udręce i cierpieniu. Być może odegrały one pewną rolę w porzuceniu przez nią religii. Być może - zwłaszcza w przypadku Boccaccia - znaczenie miał żywiołowy erotyzm tych tekstów. Sfera seksualna stanowi ten aspekt życia służących, który - także ze względu na strukturę źródeł - zajmuje poczesne miejsce w badaniach historycznych (zob. Poniat 2014, 281-287), przyciagała ona bowiem uwage policji, budziła ekscytację gazet i oburzenie moralistów. Nie ulega wattpliwości, że samotne dziewczyny, oderwane od pozostawionych na wsi lub w miasteczku rodzin, skazane na mieszkanie w domach osób je zatrudniających, padały ofiarą przemocy seksualnej - często ze strony zatrudniających je „ojców rodzin” i paniczów poszukujących możliwości seksualnej inicjacji. Z drugiej strony samotność mogła również skłaniać do śmielszego dążenia do kontaktów seksualnych. Wśród kobiet rodzących nieślubne dzieci dominowały właśnie służące, przy czym „ojcami nieślubnych dzieci rodzonych przez służące byli zazwyczaj mężczyźni o zbliżonej do nich pozycji” (Poniat 2014, 282). Ten wymiar życia, poddawany szczególnie intensywnym praktykom dyskursywnym, w których splatały się dyscyplinujące moralizowanie i fantazmatyczne obrazy, pozostaje dla nas ostatecznie niedostępny. Być może zresztą winniśmy powtórzyć wątpliwość, którą Zemon Davis wyraża ustami bohaterek swej książki: „O tym akurat lepiej milczeć”.

Relacje międzyludzkie, przyjaźń, miłość, stanowią w biografii Etli Bomsztyk kwestię okrytą wyjątkowo szczelną warstwą milczenia - poza tymi, rzecz jasna, które dotycza 
towarzyszek roboty związkowej i partyjnej, a także współwięźniarek: tu relacje dostarczają długiej i niezwykle cennej listy nazwisk. Forma narracyjna wypracowana przez partię pozwala więc mówić, ale i skazuje na milczenie. Szczególnie wyraźnie ujawnia się to w historii małżeństwa Etli. Relacje nie mówią o nim ani słowa (Bomsztyk wyszła za mąż po wyjściu z więzienia, a zatem w czasie, o którym nie mamy już informacji). W życiorysie z roku 1944 pojawia się jedno suche i nieporadne zdanie: „W r[oku] 1935 zeszłam się z tow[arzyszem] bezpartyjny komunista [s]"77. Istnieje jednak daleko pełniejsza narracja o mężu Etli Bomsztyk - o chłopaku, który zobaczył jej zdjęcie, kiedy była w więzieniu, zakochał się i czekał na jej uwolnienie (Zob. Ciałowicz 2016, 27) ${ }^{78}$.

Niewiele też wiemy o przyjaźni i wsparciu płynącym nie z rewolucyjnego zaangażowania, lecz z samej tylko solidarności wobec wspólnego losu. W zakończeniu tekstu poświęconego związkom zawodowym zrzeszającym służące Monika Piotrowska-Marchewa pisze:

Wiele wskazuje na to, że [...] w codziennym życiu więcej dla służących znaczyły układy koleżeńskie niż związi zawodowe, zarówno te patronackie, jak i klasowe. Nie upolitycznione organizacje, a zwykła solidarność koleżeńska, nieraz krucha, wykształcona w najbliższym sasiedztwie, zawsze na gruncie zawodowym, była pierwszym i instynktownie wybieranym źródłem pomocy (Piotrowska-Marchewa 2009, 221).

Piotrowska-Marchewa cytuje pamiętnik Józefy Witowskiej, która udzielała na noc schronienia bezdomnym koleżankom: „Pani się trochę domyślała, ale kręciłam, jak mogłam [...]. Były noce, że cztery u mnie spały. Po cichutku i po ciemku wpuszczałam je po jednej do mego pokoiku. Dwie spały ze mną w łóżku, dwie w ogromnej skrzyni” (Witowska 1951, 113; za: Piotrowska-Marchewa 2009, 222). Etla Bomsztyk wspomnienia o swojej przedpolitycznej młodości kończy uwagą: „Mój mizerny, chorobliwy wygląd dawał małe szanse zdobycia posady. Odnalazłam koleżankę Asnę, która była na posadzie. Wkradam się do niej do kuchni, gdzie dzieli się ze mną swoim jedzeniem. A najgorzej jest ze spaniem. Muszę przychodzić, gdy gospodarze śpią...".

I, jak gdyby chciała zamknąć klamrą to wspomnienie, Etla dokonuje cięcia, powracając w ostatnim zdaniu do narracji z pierwszego akapitu: „Aż nadszedł okres bardzo ważny w moim życiu. Był rok 1918-[19]19. Dzięki zwycięstwu Rewolucji Październikowej Polska uzyskała niepodległość”. To już zapowiedź Ongiś tak było.

\footnotetext{
77 Życiorys z grudnia 1944. Zastrzeżenie, że Izrael Rozmaryn, choć bezpartyjny, był jednak komunistą, wydaje się nieprzypadkowe. Jak widzieliśmy, podobna uwaga znalazła się w opinii Łazebnika.

78 Informacja przekazana przez przyjaciółki Etli Bomsztyk.
} 
Spisana w 1953 roku relacja Etli Bomsztyk jest historią osobistego dojrzewania, samodzielnych poszukiwań, narastającej woli oporu. Świadectwem tych myśli i działań, które stanowiły przesłankę politycznego zaangażowania, lecz które znalazły w nim jedynie częściową artykulację. Na tę „mniejszą historię” - rozbłyskująca za sprawą i zarazem poza narracja partyjną, której sztywne ramy rozsadza - składa się cierpienie i miłość, filozofowanie i tanie książeczki, a nade wszystko materialne, cielesne doświadczenie, łączące Etlę ze światem i z wielotysięczną masą istnień ludzkich skazanych na milczenie.

\section{Aneks}

\section{Dokument $1^{79}$}

\section{[1] Dzierżoniów, dnia 18.V.1953 r.}

... Pamiętam Polskę - tę sprzed września, bogatą w przepych i nędzę największą, kraj panów i sług. Codzienny trud robotnika wzbogacał panów, lecz by codziennie używać, rozkoszować się tym bogactwem, burżuazja zatrudniała innego rodzaju robotnika, który był bezpośrednim wykonawca wszystkich jej kaprysów i zachcianek. Tym wykonawcą była niezliczona masa robotnic domowych - służba domowa. Nieopisanie ciężki był los tych dziewcząt, które nędza wygnała z domu, ze wsi i miasteczek. W mieście, nie mając dachu nad głową i pozbawione możności zarobienia na utrzymanie się, gdyż panowało bezrobocie, zmuszone były iść na ten niewolniczy kawałek chleba.

Jedna z nich byłam ja.

Urodziłam się w małym miasteczku Lipsko n[ad] Wisłą. Żyliśmy w skrajnej nędzy. Rodzina nasza liczyła 11 osób. Gdy głód i choroby dokuczały nam coraz mocniej - czuliśmy żal do matki, że nas tyle miała, a nie mogła dać nawet chleba. Wówczas odpowiadała nam, iż pan bóg [s] daje dzieci, więc ich nakarmi. Trzeba go tylko o to prosić i czekać cierpliwie, aż prośbę usłyszy. Tak pocieszała nasze zgłodniałe żołądki. Była bardzo cierpliwa i wytrwała. Ojciec był 100\% analfabeta. Zawodu nie miał żadnego, gdyż rodzice jego uważali, że szewc lub krawiec poniża godność rodziny. Mówiło się wówczas: szewcy, krawcy - to nie ludzie. Do handlu nie miał żadnych zdolności. Najmował się więc do każdej natrafionej roboty. Do najlepszych zajęć ojca należało kręcenie na ręcznym młynie tatarki na kaszę. Za pracę od

\footnotetext{
${ }^{79}$ Mps., zbiory autora. W transkrypcji przyjęto zasadę maksymalnej wierności wobec oryginału i dokonano jedynie korekt oczywistych pomyłek ortograficznych i interpunkcyjnych. Zachowano wielkie i małe litery stosowane w zapisie oryginalnym. Skróty rozwijane są w nawiasie kwadratowym.
} 
świtu do nocy dostał 30 kopiejek i trochę kaszy. Na swą ciężką pracę nigdy się nie skarżył. Wszyscy w rodzinie byli szczęśliwi, że na obiad będzie kasza z mlekiem, a na śniadanie chleb. Lecz to trwało niedługo. Robota była wtedy, gdy właściciel młyna sprzedał kaszę zmieloną i kupił znowu tatarkę. Trwało to nieraz kilka miesięcy. Wówczas nędza była okropna. Z wycieńczenia zachorowaliśmy na oczy, z braku mydła i strasznego brudu toczył nas świerzb. Nieraz sekretarz gminy posyłał ojca do m[iasta] pow[iatowego] Iłży z pismem. Taki posłaniec wynosił taniej niż koń, któremu oprócz pokarmu trzeba dać furmana. Ojciec wychodził o świcie, zabierał w kieszeni kawałek suchego chleba, który mama brała na borg ${ }^{80}$ na konto tego zarobku. Wracał na drugi dzień śmiertelnie znużony, lecz z uczuciem zadowolenia, że zarobił na kilkudniowy chleb dla nas, na mydło i zapłacenie podatku za drewnianą budę, która była naszym domem. W razie niezapłacenia podatku poddano by nas licytacji. Dwoje dzieci umarło z głodu. Zmniejszyła się rodzina, lecz nie nędza. Najeść się chleba do syta było marzeniem, chociaż funt kosztował zaledwie 3 kopiejki. Gdy matka, nie mając już zębów, odkroiła ze swej porcji skórkę - nie wiedziała komu ją wpierw dać.

Tak rosłam mizerna, słaba i apatyczna. Gdy miałam 9 lat, zachorowałam na czarna ospę. Miesiąc czasu leżałam bez opieki lekarza, gdyż nie było pieniędzy na jego opłacenie. Gdy wstałam z łóżka, które zamykało się deską i w dzień służyło za ławkę - byłam prawie ślepa, wyczerpana. Wtedy, z litości nade mną, sąsiadka wzięła mnie do pomocy w sklepie na dni jarmarczne. Ponieważ była ze mnie zadowolona (dobrze liczyłam jajka, które chłopi zamieniali na naftę), dawała mi dziennie 50 kopiejek i coś do zjedzenia. Jarmarki odbywały się co dwa tygodnie. Czekałam z niecierpliwościa na te dni. Marzyłam o tym, by jakiś bogaty chłop zgubił chociaż kopiejkę, by se [s] kupić za nią wody sodowej. Ale cudu nie było. Zaczęłam myśleć o wyjeździe do dużego miasta, by znaleźć pracę, najeść się do syta i pomóc rodzinie. Ale jak jechać, gdy nie ma pieniędzy na podróż, na ubranie? Nędza wygania jednak $z$ domu. Najstarsza siostra od dwóch lat pracowała jako robotnica domowa w Radomiu. Mama ukrywała tę prawdę przed ludźmi. Starszy brat chodził 4 lata do rosyjskiej szkoły. Płacił za niego dziadek, który już nie żył. Reszta dzieci nie widziała nigdy szkoły. Brat nauczył nas abecadła, reszty uczyło nas życie, bo brat musiał wyjechać do Warszawy w poszukiwaniu pracy. Był bardzo zdolny. Udzielał lekcji początkującym uczniom, dzieciom drobnomieszczańskim. Zajmował kąt u biednej rodziny przy ul. Wołyńskiej. [2] To zabierało mu pieniądze zarobione w ciagu tygodnia, reszta zaledwie starczy[ła] na marne wyżywienie. Najradośniejsze w życiu rodziny były chwile spędzane z bratem, gdy przyjeżdżał do domu na święta. Opowiadał o Warszawie, o kinie, w którym był zaledwie raz w ciagu roku. Śpiewał nam piosenki zasłyszane na warszawskich podwórkach. Śpiewali je niewidomi, którym

\footnotetext{
${ }^{80}$ Tzn. na kredyt.
} 
bogate, miłosierne panie rzucały resztki swych przepełnionych stołów, czerstwy chleb lub parę groszy. Był jakby promieniem słonecznym w naszym ponurym życiu. Później przywoził książeczki, które czytałam rodzeństwu. Zapominaliśmy przy tym o głodzie i innych dolegliwościach. Uczyłam młodszych braci abecadła. Wkrótce byliśmy wszyscy jednakowo uczeni. Przywoził również gazety. Czytał na głos. Wiele ludzi przychodziło posłuchać. Tłumaczył, opowiadał, lecz ja nic z tego nie zrozumiałam. W miasteczku mówiono, że jest filozofem i bezbożnikiem. Rodzice, chociaż byli bardzo pobożni, jakoś nie przejęli się tym. Przeciwnie, stał się chlubą naszej rodziny. Pragnęliśmy mu wszyscy dorównać. Radość trwała krótko, ponieważ był w wieku poborowym - wzięto go do wojska. Było mu bardzo źle, pisał smutne listy. Po dwuletniej służbie wrócił znów do Warszawy. W 1914 r. na Wielkanoc brat przyjechał, by mnie zabrać do Warszawy. Mama bardzo płakała, bo zrozumiała, że czeka mnie los robotnicy domowej. Ale brat powiedział, że dla mnie jest to zło konieczne, zapewniał, że weźmie mnie do ludzi dobrych, gdzie udziela lekcji, że będę traktowana dobrze, a później może uda się mnie nauczyć zawodu. Matka wreszcie zrezygnowana, z bólem serca zgodziła się. Nie było przecież innego wyjścia.

Do Warszawy pojechaliśmy statkiem, to wynosiło taniej niż pociagiem, bo do stacji do Radomia trzeba było jechać całą noc. Do miasta doszliśmy [na] piechotę. Trzymałam się kurczowo marynarki brata. Nie byłam nawet podobna do dzisiejszej 14-to letniej [s] dziewczyny, byłam wstydliwa, zawsze smutna, głowę trzymałam nisko schyloną. Warszawa zrobiła na mnie oszołamiające wrażenie. Weszliśmy do dwupokojowego mieszkania parterowego przy ul. Muranowskiej 24. Niska młoda blondynka pokazała mi mieszkanie i w obecności brata powiedziała, że będzie mnie traktowała jak własne dziecko. Zaraz przystapiła do wyliczenia moich obowiązków, a więc rano iść po mleko i pieczywo, oczyścić panu buty, froterować podłogi i prać całą bieliznę. A jak to wszystko zrobić - pokaże, bo jest przecież w domu, a gotować mnie nauczy. O pensji nawet mowy nie było. Czyź nocleg i jedzenie nie wystarczy? Tak zaczęłam nowe życie. Strasznym ciężarem ugniatała, toczyła mnie tęsknota za matką i rodzeństwem, do których byłam bardzo przywiązana. Praca męczyła mnie bardzo, szczególnie pranie, które potrzebowało większej niż moja - siły. Nie mogłam już nawet jeść z powodu tęsknoty i wyczerpania. Gdy brat, któremu o tym z płaczem opowiedziałam, zaproponował mi powrót do domu - odpowiedziałam stanowczo, że muszę się przyzwyczaić i tak wyrobić, by pomóc rodzinie, a jeśli nie potrafię tego przewalczyć, wolę umrzeć, a do poprzedniej nędzy nie wrócę. Tak mijały miesiące, aż nadeszło zło przekraczające dotychczasowe. Nadszedł 1 sierpień. Wybuchła 1-sza wojna światowa. Powszechna mobilizacja zabiera drogiego mi brata. Nie liczę się już z gospodynią. Całe dnie spędzam na punkcie zbornym przy ulicy Pokornej, która roi się od ludzi. Płaczę, rozpaczam razem z rodzinami żegnającymi braci, ojców, mężów. Zrozumiałam tylko, że wyjadą gdzieś daleko na wschód, a ja zostanę sama bez brata. Złamana, zrozpaczona 
wróciłam do chlebodawcy. Zaczynają się dni ciężkie, myśl o tym, że brat może zginąć, zabiera sen. Rodzice moga lada dzień zostać bez dachu nad głowa. Całą noc trzeba stać w kolejce, by dostać bochenek kasztanowego chleba. Gospodyni zaczyna oszczędzać przede wszystkim na mnie. Instytucja, w której pracowal chlebodawca - likwiduje się. W związku z tym tracę pracę. Przez litość przekazuja mnie do swej kuzynki, która mieszka na Złotej nr 40, ma sklep galanteryjny i pewien zapas towarów, które z dnia na dzień drożeja. Tak więc nie myślę już o zawodzie, jestem zadowolona, że w takim ciężkim czasie nie jestem na bruku. Bezrobocie rośnie z każdym dniem. Nie mam już domu, wojsko carskie wysiedliło ludność cywilną i spaliło rodzinne miasteczko przed nadejściem Austriaków. Rodzice z trzema braćmi pieszo zawędrowali do Warszawy. Trudno opisać ówczesne moje położenie. Cały dzień rodzice wędrowali po mieście w pogoni za wodnistą zupką filantropijnych kuchen, a wieczorem, gdy gospodarze kładli się już spać, wpuszczałam ich po kryjomu do kuchni, gdzie spali kilka godzin na samej podłodze. W obawie przed chlebodawcami budziłam ich przed świtem i z bólem w sercu wyganiałam na ulicę. Starałam się ze wszystkich sił zadowolić gospodarzy. Po jakimś czasie, gdy Austriacy i Węgrzy usadowili się w Lipsku, rodzina wróciła tam i zaczęli sobie na gruzach sami budować coś, co miało być domem. Żyli z tego, co posyłam ja lub siostra z Radomia. Było to za dużo, by umrzeć i za mało, by żyć... Ciagle ktoś inny chorował z braku najelementarniejszych warunków. Brat pisał listy z różnych frontów.

[3] Do domu nie chciał wracać. Wstąpił do partii bolszewickiej. W 1918 r. zginą w walce $z$ kontrrewolucja. Bardzo ciężko przeżyłam tę stratę. Tak płynęło moje życie w udręce, cierpieniach, bez słońca i radości, w wyniku czego przestałam wierzyć w boga, zaniechałam modlitwy, gdy przekonałam się, że w życiu moim nie ma poprawy, a zło nie ma końca, że muszę sama walczyć o swój byt. Wielkie było moje rozczarowanie w to, co czytałam w modlitewniku i w to, co opowiadała mama. Zaczęłam filozofować, rozmyślać, szukać odpowiedzi na dręczące mnie kwestie. Poczęłam czytać książki, które popadły [s]. Potem zapisałam się do czytelni przy ul. Mariańskiej. Gdy szłam po zakupy, wkradałam się do czytelni po książki, które czytałam po kryjomu w nocy, bo co to za służąca, co czyta książki? Czytałam chaotycznie, Tołstoja i Bocaci'ego Hermalina itd. W 1916 r. do Warszawy weszli Niemcy. Co bogatszy robił wszystko, by się przypodobać okupantowi. Zaczęli się uczyć j[ęzyka] niemieckiego. Bardzo chciałam się uczyć i w tym celu przypochlebiałam się dzieciom chlebodawcy, mając nadzieję, że podzielą się trochę swą wiedzą. Osiemnastoletnia córka gospodarzy czasem późno wieczorem uczyła mnie trochę rachunków i niemieckiego. Mało z tego skorzystałam, bo wkrótce zachorowała na tyfus. Rodzice nie chcieli jej oddać do szpitala. Trzymali ja w osobnym pokoju, a ja musiałam ja pielęgnować, bo rodzice nie chcieli się zarazić. W wysokiej gorączce bredziła o nieznanych mi rzeczach. Zrywała się 
z okrzykiem: policja, ścigają! Najczęściej wzywała Karola i Szpinaka ${ }^{81}$. Ja i jej stara, ślepa babcia, której o tym opowiedziałam, myślałyśmy, że chodzi o sprawy miłosne. Lecz później, gdy w pracy partyjnej spotkałam się z tymi nazwiskami, to zrozumiałam to, co było dla mnie wtedy tajemnica. Na skutek Rewolucji Socjalistycznej fala rewolucyjna ogarnęła nawet mieszczańską część młodzieży szkolnej, między innymi i córkę moich chlebodawców. Często znikała z domu, a gdy wracała, w domu były awantury. Pamiętam, było to w jakieś święto, wybierała się do wyjścia z domu. Ojciec zamknął drzwi na klucz i długo się kłócili po cichu, żebym ja nie słyszała. Wtedy otworzyła okno i z parteru wyskoczyła. Wówczas nie wiedziałam, o co chodzi. Czasem podsłuchałam jej rozmowę z bratem o handlowcach $z$ ul. Zielnej, o zebraniach ${ }^{82}$. Przebieg choroby był ciężki, aż dziw, że się nie zaraziłam, będąc ciagle z nią razem. Wkrótce potem ciężko zaniemogłam. Chorobę tę nazywano hiszpanką. Leżałam kilka tygodni. Gdy wstałam słaba, niezdolna do pracy, przestali mnie nawet żywić, mimo że pracowałam u nich 3 lata. Musiałam więc pojechać do domu i zwiększyć nędzę rodziny. Po jakimś czasie musiałam znów wrócić do Warszawy. Mieszkałam tu 4 lata, a jednak nie miałam gdzie wejść przenocować. Zmuszona byłam pójść do stręczycielki, tak zwanej rajfurki ${ }^{83}$, co było dla mnie ciężkim przeżyciem. W piwnicznej, brudnej izbie przy ul. Miłej pełno było dziewcząt. Polki i Żydówki, ze wsi, miasteczek i miast, głodne i niewyspane siedziały tu w zaduchu po kilka miesięcy nieraz, chociaż w jedynie dostępnym dla nich zawodzie rob[otnic] dom[owych] nie było niby takiego bezrobocia jak w innych zawodach. Za każda przesiedzianą noc trzeba było płacić lub dać zastaw. A jak wyglądało to otrzymanie posady przez rajfurkę [?] Bywało tak, że panie przychodziły i wybierały sobie pracownice. Podobne to było do kupna konia, np. dziewczyna musiała być tęga, o zdrowym wyglądzie. Następnie odpowiadała na pytania, czy ma narzeczonego, czy lubi chodzić na spacer lub przyjmować gości. Jeśli tak, to jest nieodpowiednia. Niektóre żądały rekomendacji z poprzedniej posady. Lecz to rzadko kto posiadał. Nic nie zobowiazzywało chlebodawcy do wydania takiego dokumentu. Pracownice domowe nie były objęte żadnym prawodawstwem. Wszystko zależało od widzimisię pracodawcy. Była jeszcze inna forma stręczycielstwa. Rajfurka brała kilka dziewcząt i szła do jakiejś pani, która kazała sobie przyprowadzić robotnicę. Wpierw wprowadzała jedną, a w wypadku niepowodzenia wprowadzała następne. Towaru było dużo. Czasem doradzała, innym razem odradzała -

${ }^{81}$ Być może mowa o Józefie Józefowiczu-Szpinaku (1890-1952), współzałożycielu socjaldemokratycznej organizacji młodzieżowej Przyszłość (w 1910 roku). Szpinak został jednak aresztowany na długo przed opisywanymi w tekście wydarzeniami - w roku 1912. Po wybuchu I wojny światowej przewieziono go do więzienia w rosyjskiej Kałudze, po wyjściu na wolność pozostał w Rosji Radzieckiej.

82 Przy ul. Zielnej 25 w Warszawie mieścił się gmach Zwiazzu Zawodowego Pracowników Handlowych i Biurowych, 15 i 16 grudnia 1918 roku odbył się tam zjednoczeniowy zjazd SDKPiL i PPS-Lewicy, na którym utworzono Komunistyczną Partię Robotniczą Polski.

${ }^{83} \mathrm{~W}$ żydowskiej Warszawie rajfurkami nazywano pośredniczki załatwiające pracę służącym domowym, por. np. Hen 2011. 
zależnie od okoliczności. Czasem szła do pani, u której już pracowała robotnica i nagadała o niej tyle niesłychanych rzeczy, że wystraszona gospodyni prędko zwalniała ofiarę intrygi, by u rajfurki kupić inna, zachwalaną ogromnie. Takimi machinacjami rajfurka zarabiała podwójnie - u gospodyni, której sprzedała robotnicę, i od zwolnionej, którą stręczyła komuś innemu. Mój los także spoczął w rękach rajfurki, kobiety o niskim poziomie moralnym. Mój mizerny, chorobliwy wygląd dawał małe szanse zdobycia posady. Odnalazłam koleżankę Asnę, która była na posadzie. Wkradam się do niej do kuchni, gdzie dzieli się ze mną swoim jedzeniem. A najgorzej jest ze spaniem. Muszę przychodzić, gdy gospodarze śpią, ale trzeba wykombinować, by zdążyć przed godz[ina] 10 wejść, bo potem dozorca nie wpuści obcego. Trzeba się skurczyć w łóżku, przykryć głowę, nie oddychać, by nikt nie zauważył. Aż nadszedł okres bardzo ważny w moim życiu. Był rok 1918-[19]19. Dzięki zwycięstwu Rewolucji Październikowej Polska uzyskała niepodległość.

\section{Dokument $2^{84}$}

\section{Ongiś tak było}

Pomoce domowe zorganizowały się w związek zawodowy już w 1918 roku. Pierwszymi założycielkami związku były: Mania Cegiełka, Chajka (jej nazwiska nie moge sobie przypomnieć), Sara Wajcman i Beniamin Walker, szewc, stary rewolucjonista i dawny bundowiec. Beniamin był chorym kuternoga. Towarzysz Beniamin przeszedł na stronę komunistów i przebywał na emigracji w Związku Radzieckim. Był on wybornym mówca. $\mathrm{Na}$ samym początku to on prowadzil nasze zebrania. Wtedy nikt $z$ nas nie miał jeszcze żadnego doświadczenia w działalności w związkach zawodowych i robocie partyjnej, bo gdzie i jak mieliśmy je nabyć? Mało kto z nas umiał czytać i pisać.

Życie dziesiątek tysięcy biednych żydowskich dziewcząt w dawnej Polsce przedstawiało sobą obraz nędzy i rozpaczy: wygnane przez panująca na wsi i w sztetlu biedę, wyruszały w świat za kawałkiem chleba. Zarobić na chleb jednak wcale nie było łatwo. Bez domu, bez najbliższych, przy dużym bezrobociu, które panowało we wszystkich grupach zawodowych, wiele z nich nie miało innego wyjścia, jak tylko nająć się za służącą u bogatych państwa. A było to naprawdę życie niewolnicy. Harowało się przez cały tydzień, czasem tylko za sam wikt, od bladego świtu do późnego wieczora. Jedynie w szabes pozwalano nam wyjść na kilka godzin. Sytuacja tej, której zdarzyło się małe spóźnienie, przyszła odrobinę później, była nie do pozazdroszczenia. Dostawała od swojej „madame” nie lada burę. Nierzadko

\footnotetext{
${ }^{84}$ Publ. oryg.: E. Bomsztyk: Azoj iz gewen amol. W Goldfinger, Mirski i Zachariasz 1959: 212-214. Publ. pol.: Ongis tak było. Bomsztyk 2016: 28-29; zob. też: http://varshe.org.pl/teksty-zrodlowe/o-miejscach/221-ongi-takbyo (dostęp: marzec 2017).
} 
zdarzało się, że ze taki „grzech” madame od razu wyrzucała z posady. O jakimkolwiek zasiłku socjalnym nie było mowy. Jej „,pokój” stanowiła kuchnia.

Poniżanie i upokarzanie, kaprysy „madame”, które trzeba było znosić, synalkowie i „kształcone” córeczki, lekceważący stosunek „,szejne Jidn”"85 do panien służących wpływały na wiele $z$ nas przygnębiająco, powodowały niewiarę $w$ to, że własnymi siłami możemy poprawić nasze położenie.

Przypominam sobie, ile wysiłku i potu kosztowało nas, grono uświadomionych pomocy domowych, stworzenie związku zawodowego. Zwołując pierwsze zebranie, pokonałyśmy niezliczoną ilość pięter. Chodziłyśmy od mieszkania do mieszkania, aż zebrałyśmy kilkadziesiąt panien służących. Zebranie odbyło się w prywatnym mieszkaniu pewnego rymarza, w suterenie przy świeczce, przy ul. Nalewki 32. Niewielka liczebnie była grupa osób, które wzięły na siebie trudne zadanie założenia związku zawodowego. Lecz powodowane biedą i silną wolą polepszenia naszego losu, stopniowo doprowadziłyśmy do sytuacji, w której w 1921 roku związek liczył już ponad 300 członkiń. Ze składek członkowskich byłyśmy w stanie opłacić sekretarza i duży lokal przy ul. Długiej 61.

Fala rewolucyjna, która w tamtych latach porwała szerokie masy społeczeństwa żydowskiego, a także członów Bundu, nie ominęła również panien służących. W naszym związku większość sympatyzowała z „Kom-Bundem”. Później związek nasz znalazł się w sferze wpływów Kompartii.

Przyszło nam działać w skrajnie trudnych warunkach. Lokal związku został zamknięty w 1923 roku z powodu ujawnienia pierwszej krajowej konferencji młodzieży żydowskiej, która tam się odbywała. To jednak nas nie przestraszyło. W sieniach związku drobnych kupców przy ul. Leszno ustawiło się stolik i robota szła dalej. Udaje nam się wywalczyć polepszenie warunków pracy i płacy. W pierwszym rzędzie: legalizację związku wraz [z] zakazem zwalniania bez wiedzy związku. Dalej: trzy razy w tygodniu wolny wieczór, kasa chorych, urlop i ludzkie traktowanie.

Jak wiele związków, którym przewodzili komuniści, tak i nasz związek nie uniknął szykan ze strony policji. Co kilka miesięcy związek zamykano. Nie pomagała zmiana nazwy lub podpisy za każdym razem innych osób na podaniu o zalegalizowanie. W ten sposób byłyśmy zmuszone prowadzić naszą działalność na ulicy, nielegalnie, na tak zwanych „giełdach”. W najtrudniejszych warunkach, na mrozie i w śnieżycy. Przeganiane z jednego miejsca, przenosiłyśmy się na inne miejsce. Nie dopuściłyśmy do tego, by służba domowa była zdana na widzimisię rajfurek i różnych „madames”.

Prócz działalności związkowej prowadziłyśmy także robotę polityczną i partyjna. Komórka partyjna w latach 1927-1928 liczyła około 50 członkiń i była obsługiwana przez

\footnotetext{
85 „Szejne Jidn” (l.mn., jid., „piękni Żydzi”) - elita duchowa, ludzie jaśniejący wewnętrznym blaskiem (przyp. tłum.).
} 
towarzyszy: Szymona Zachariasza, Jonę Dzbanka, Mosze Grinbauma (głuchego), Adelę Herc, Judla Rozenfelda, Abrahama Rozenfelda, Fajwla Malarza, Karola ze związu pracowników igły i innych, których nazwisk już nie pamiętam. Mieliśmy także spore koło MOPR, które było obsługiwane przez towarzyszy Chaima Kramarza, Lubę Szmulowicz i Helenkę Graff.

Czerwona frakcja w liczbie 80 osób była obsługiwana przez drogich i oddanych towarzyszy Gecla Gutermana ze związku piekarzy i Bernarda Frajdkesa, który poległ śmiercią bohaterska w Hiszpanii. Największe zasługi miał towarzysz Sender Kaner (Sender „Masowiec” - malarz). On i inni poświęcili ogrom trudu i czasu na rzecz organizacji panien służących.

Nie oglądając się na szczególnie trudne warunki, brałyśmy udział we wszystkich demonstracjach, rozklejałyśmy plakaty, kolportowałyśmy prasę partyjną, oddawałyśmy do dyspozycji lokale naszych gospodarzy, kiedy ci wyjeżdżali na daczę, na posiedzenia i składy nielegalnej literatury. Pracując później jako łączniczka Centralnego Biura Żydowskiego i sekretariatu Komitetu Centralnego KPP największą pomoc miałam ze strony towarzyszek służących.

Do najbardziej oddanych związkowi i partii, o ile dobrze pamiętam, należały między innymi: Ester Szpaker (otrzymała wysokie odznaczenie państwowe ze działalność rewolucyjna), Hela Leks, Róża Migdał, Róża Wajnworcel, Ida Bersztajn (obecnie przebywa w związku Radzieckim).

Sala Jedlina - wspaniała postać, zginęła w białostockim getcie. Głodni i prześladowani komuniści mogli u niej zawsze znaleźć schronienie. Była oddana partii na śmierć i życie. Chana Kotlarz, która towarzysze nazywali „Aniołkiem”. Wskakiwała na stragan na bazarze przy ul. Smoczej i prowadziła masówki dla żydowskiej biedoty, wzywając ją do walki przeciwko wysokim podatkom, drożyźnie i eksmisjom. Jej ciemna izba kuchenna, gdzie pracowała przy ul. Niskiej, służyła za stały skład nielegalnej literatury.

Takie one były, te pomoce domowe - najbardziej poszkodowane i najbardziej prześladowane ze wszystkich poszkodowanych i prześladowanych. Dopiero Kompartia wprowadziła je do szeregów walczącego proletariatu i uczyniła z nich to, co opisałam powyżej: bojowniczki. 


\section{Dokument $3^{86}$}

\section{$[1]$}

\section{Życie komuny więźniarek politycznych więzienia „Serbia” w Warszawie}

\section{Relacja Bomsztyk Edwardy nagrana w ZHP dnia 14.VI.1966 r. ${ }^{87}$}

Pierwszy raz zostałam aresztowana podczas wyborów do Kasy Chorych w 1926 r. Byłam na liście kandydatów i o drugiej w nocy przyszedł do mnie policjant z nakazem rewizji $\mathrm{i}$ aresztowania. W czasie rewizji robiłam wszystko $\mathrm{w}$ zwolnionym tempie, ażeby podrażnić policjanta. W pewnym momencie policjant podniósł blat stołu i znalazł wewnattrz moc obciążających mnie materiałów. To były materiały zawierające dyskusje majową na temat błędu majowego ${ }^{88}$. On to wszystko zabrał i poszedł ze mną. Odnosił się do mnie bardzo uprzejmie. Szliśmy przez Bielańską. Na znajdującym się tam skwerku policjant mnie zostawił na chwilę, którą mogłabym ewentualnie wykorzystać na ucieczkę. Powiedziałam to policjantowi, ale on stwierdził, że był spokojny, iż ja nie ucieknę i zaprowadził mnie do defenzywy $[\mathrm{s}]^{89}$. Tam było strasznie dużo ludzi, bo w dniu wyborów zamknięto [2] wielu kandydatów i wyborców, ażeby było jak najmniej głosów. Policjant wprowadził mnie do dużego gabinetu naczelnika defy, pożegnał się ze mną uprzejmie, a nawet uśmiechnął się do mnie. Gdy skończyły się wybory, zaczęto zwalniać aresztowanych. Znajomym, z którymi się zetknęłam w defie, powiedziałam, co u mnie znaleziono w czasie rewizji i prosiłam ich, żeby dali znać, gdzie trzeba. Byłam pewna, że będę siedzieć. Jakie było moje zdumienie, gdy wezwano mnie do naczelnika, a ten dał mi przepustkę do wyjścia na wolność. Zorientowałam się, że policjant nie oddał w defie znalezionych u mnie materiałów. W KW [Komitecie Warszawskim] dostałam burę za to, że nie popatrzyłam na numer tego policjanta.

P o raz drugi aresztowana byłam w 1928 r. Była wtedy wielka wsypa. Ze mną razem aresztowano dwóch braci i dwie siostry Upfał z ul. Muranowskiej, z których tylko najmłodsza siostra była zaangażowana. W czasie rewizji ona wyrzuciła przez okno jakieś materiały i to

\footnotetext{
86 Mps. AAN, nr zespołu 1581; Zbiór relacji dotyczących ruchu robotniczego (1956-1989), sygn. R-182. Życie komuny więźniów politycznych w kobiecym więzieniu Serbia. Komuna więźniów politycznych w kobiecym więzieniu „Serbia”w Warszawie, relacja 17 - Bomsztyk Edwarda.

87 Tekst spisany z taśmy magnetofonowej.

${ }^{88}$ Mowa o poparciu przez KPP zamachu majowego Józefa Piłsudskiego w 1926 roku.

89 Defensywa (Defa), Inspektorat Defensywy Politycznej - nazwa utworzonej w 1919 roku policji politycznej, podlegającej Komendzie Głównej Policji Państwowej.
} 
było przyczyną zatrzymania całej czwórki. Bracia byli bardzo pobożni, nosili kapoty, mieli pejsy i przez 3 dni pobytu $\mathrm{w}$ defie niczego nie wzięli do ust, żądali przyniesienia im przyborów do modlitwy, bo bez rannej modlitwy nie mogli jeść. Defa zorientowała się, że to jest jakaś pomyłka i na trzeci dzień wypuściła tych dwóch braci. Nas natomiast trzymano w defie 4 dni w okropnych warunkach.

Po przyjściu na „Serbię” zostałam skierowana do celi z tą starszą siostra, która również była ofiara, jak jej dwaj bracia. Było z nią bardzo ciężko siedzieć. Przez cały dzień płakała. Po kilku dniach zwolniono ja. Ja zostałam zwolniona po dwóch miesiącach.

[3] Z tego okresu niewiele pamiętam, nie byłam zresztą wciągnięta w życie komuny, może dlatego, że siedziałam tylko z tą kobieta.

Po raz trzeci wpadłam w 1932 r. Byłam wówczas łącznikiem między sekretariatem KC a okręgami. Byłam bardzo obciążona. Przesłuchiwał mnie wtedy Pogorzelski ${ }^{90}$. On rozmawiał ze mną bardzo grzecznie, niczego nie wymuszał, lecz tłumaczył, że ta idea jest utopią, że ona się nigdy nie urzeczywistni i że nie warto iść na kilka lat do więzienia, gdzie nieuchronnie dostaje się gruźlicę. Nie wdawałam się z nim w rozmowy, odpowiadałam tylko, że to moja sprawa. Z defy odesłano mnie na Serbię, gdzie siedziałam od marca do listopada $1932 \mathrm{r}$.

Najpierw siedziałam w dużej 11 celi na II piętrze. Przez tę celę przewinęło się w tym czasie dużo towarzyszek. Przychodziły i wychodziły. Była wtedy w tej celi Sarenka Firstenberg, Dorka Finder. Później przeniesiono mnie do małej celi, w której siedziałam z Maria Hering i Zofia Dorosz. One były znacznie starsze ode mnie. Bardzo dobrze się z nimi siedziało. Zofia Dorosz była bardzo inteligentną kobietą. Ja byłam robotnica, miałam tylko doświadczenie z pracy partyjnej, ale nie miałam wykształcenia. One starały się nauczyć mnie wszystkiego, co tylko mogły, szczególnie ta Dorosz, bo Maria Hering była chorowita kobieta.

Zaznaczam, że życie na Serbii było znacznie lżejsze niż w Sieradzu na przykład, gdzie odsiadywałam wyrok, $\mathrm{i}$ w innych więzieniach. W porównaniu $z$ innymi więzieniami to był niemal pensjonat. Dzień szybko mijał na nauce i na wielu innych zajęciach. O ile mnie pamięć nie myli, to w tym czasie w kierownictwie były następujące towarzyszki: Sarka Bryn [Sara Brun], Bela Frisz i Maja Gincig. [4] Nastrój i współżycie między towarzyszkami było w zasadzie w każdym więzieniu dobre, ale tak jak na Serbii to chyba nigdzie. Niezwykła opieka nad chorymi, które wyręczano od dyżurów, wszystko było skrupulatnie dzielone, żeby nikogo nie skrzywdzić, a wiara w nasze zwycięstwo była na Serbii po prostu niezachwiana.

\footnotetext{
90 Zapewne Henryk Pogorzelski, w okresie międzywojennym podkomisarz Policji Państwowej (Defensywy), zajmował się zwalczaniem ruchu komunistycznego. Po II wojnie światowej aresztowany i skazany na karę śmierci zamienioną na 15 lat więzienia.
} 
Kontakty z wolnością były załatwiane przez oddziałowa. Była to wysoka, szczupła blondynka. Nazwiska jej nie pamiętam. Z Pawiakiem natomiast utrzymywany był kontakt przez dentystę. Zofia Dorosz chodziła do dentysty, wynosiła i przynosiła grypsy. Ja byłam delegatką celi, nie powinnam więc była narażać się, Maria Hering była chora, więc tylko Zofia chodziła na Pawiak do dentysty. Kontakty z wolnością były utrzymywane również za pomoca paczek.

Podczas mego dziesięciomiesięcznego pobytu na Serbii nie było jakiejś poważniejszej akcji.

Nie dawałyśmy się badać obyczajowo ${ }^{91}$ i urządzałyśmy manifestacje w święto majowe i listopadowe. Przypinałyśmy wówczas kokardki, które nam zrywano często wraz z kawałami ubrania. W takich wypadkach składałyśmy protestacyjne oświadczenia protestujemy przeciwko przemocy, albo ustępujemy wobec przemocy. Gdy pozbawiono nas spaceru, protestowałyśmy nieprzyjmowaniem obiadu czy kolacji. Spacery odbywały się razem, tzn. wszystkie piętra równocześnie, czego nie było w żadnym innym więzieniu karnym.

Chcę jeszcze dodać parę słów o bezpartyjnych. Jak już wspomniałam, siedziałam z Marią Hering i Zofią Dorosz. Zofia Dorosz była ze Lwowa z Luckiej sprawy ${ }^{92}$. Ona wyszła za dużą kaucją, a Maria była bardzo chora i też jakoś wyszła i do mo-[5]jej celi dano Edzię Bursztyn i jedną bezpartyjna, tzw. ofiarę. Starałam się przekazać tej bezpartyjnej wszystko, co zdobyłam dzięki Marii i Zofii. Partyjnie byłam dobrze wyrobiona i postanowiłam sobie za cel wychować tę „ofiarę” na dobra partyjniaczkę. Z przyjemnością stwierdziłam później, że to mi się udało. Spotkałam ją w 1941 r. w Białymstoku. To była szczerze oddana naszej sprawie towarzyszka. Ona zawsze wspominała, że mimo iż od niej mniej umiałam (ona była nauczycielka), to dzięki mnie wiele zrozumiała i stała się człowiekiem idei. Co z nią teraz się dzieje - nie wiem.

91 Andrzej Wolica pisał w styczniu 1933 roku w liście otwartym do Związku Literatów w Warszawie „Więźniarki polityczne nowy regulamin równa z prostytutkami, wymuszając przymusową kontrolę obyczajową [...], przy czym podkreślić należy sadyzm i zezwierzęcenie naczelniczki więzienia kobiecego w Warszawie (Serbja)". AAN, teczka osobowa 8463, Wolica Andrzej.

92 Proces łucki - przeprowadzony w Lucku w 1934 roku proces działaczy i działaczek Komunistycznej Partii Zachodniej Ukrainy oskarżonych z art. 97 Kodeksu karnego. 45 oskarżonych skazano na kary od 3 do 8 lat więzienia, większość została zwolniona na mocy amnestii w 1935 roku. 


\section{Wykaz literatury}

\section{Materiały archiwalne}

Archiwum Akt Nowych

nr zespołu 1534, KC PZPR w Warszawie. Pion Organizacyjny. Wydział Polityki Kadrowej. Centralna Kartoteka, sygn. 289 (dawna sygn. CK/290), Bomsztyk Etla.

nr zespołu 1581; Zbiór relacji dotyczących ruchu robotniczego (1956-1989). Sygn. R-182. Życie komuny więźniów politycznych w kobiecym więzieniu Serbia. Komuna więźniów politycznych w kobiecym więzieniu „Serbia” w Warszawie. Relacja 17 - Bomsztyk Edwarda.

nr zespołu 349; Komenda Główna Policji Państwowej w Warszawie. Wydział IV. Centrala Służby Śledczej. Referat VI Specjalny.

Edwarda Bomsztyk, teczka osobowa 14118.

Andrzej Wolica, teczka osobowa 8463.

\section{Źródła drukowane i opracowania}

Asz, Szalom. [dostęp: marzec 2017]. Warszawa 1914. Tłum. Anna Ciałowicz. http://varshe.org.pl/teksty-zrodlowe/o-miejscach/33-warszawa-1914

Bańkowska, Aleksandra i Tadeusz Epsztein (oprac.). 2013. Archiwum Ringelbluma. Konspiracyjne Archiwum Getta Warszawy. T. 11: Ludrie i prace „Oneg Szabat”. Warszawa: Wydawnictwa Uniwersytetu Warszawskiego.

Bomsztyk, Edwarda. 2016. „Ongiś tak było”. Tłum. Anna Ciałowicz. Kolbojnik. Biuletyn Gminy Wyznaniowej Żydowskiej w Warszawie 1 (82): 28-29.

Ciałowicz, Anna. „Kwintesencja”. Kolbojnik. Biuletyn Gminy Wyznaniowej Żydowskiej w Warszawie $1(82): 27$.

Deleuze, Gilles i Félix Guattari. 2017. Kafka. Ku literaturze mniejszej. Tłum. Anna Zofia Jaksender, Kajetan Maria Jaksender. Kraków: Eperons-Ostrogi.

Furet, François. 1963. « Pour une définition des classes inférieures à l'époque moderne ». Annales. Économies, Sociétés, Civilisations 18/3: 459-474.

Ginzburg, Carlo. 1989. Ser i robaki. Wizja świata pewnego mlynarza z XVI w. Tłum. Radosław Kłos. Warszawa: PIW.

Ginzburg, Carlo. 1991. "Checking the Evidence: The Judge and the Historian." Critical Inquiry 18/1: 79-92.

Goldfinger, Hersz, Michał Mirski i Szymon Zachariasz. 1959. Unter der fon fun KPP. Artiklen, zichrojnes, dokumenten. Warszawa: Książka i Wiedza.

Grabski, August. 2004. Džiałalność komunistów wśród Żydów w Polsce (1944-1949). Warszawa: Trio.

Hass, Ludwik. 1963. Organizacje zawodowe w Polsce 1918-1939. Warszawa: Wydawnictwo Związkowe CRZZ.

Hen, Józef. 2011. Nowolipie. Najpiekniejsze lata. Warszawa: Wydawnictwo W.A.B. 
Kassow, Samuel D. 2010. Kto napisze naszq historię? Ukryte Archiwum Emanuela Ringelbluma. Tłum. Grażyna Waluga, Olga Zienkiewicz. Warszawa: Amber.

Kopczyński, Michał. 2000. „Służba domowa jako grupa zawodowa w Europie XV-XX”. W Kobieta i praca. Wiek XIX i XX. Red. Anna Żarnowska, Andrzej Szwarc. Warszawa: Wydawnictwo DiG.

Kormanowa, Żanna. 1975. „Z działalności związkowej pracownic domowych w Warszawie na Żoliborzu (1931-1939)". Kwartalnik Historii Ruchu Zawodowego 4: 47-59.

Marks, Karol. 1962. „W kwestii żydowskiej”. W: Karol Marks, Fryderyk Engels. Drieła. T. 1. Warszawa: Książka i Wiedza.

Marzec, Wiktor. 2016. Rebelia i reakcja. Rewolucja 1905 roku i plebejskie doświadczenie polityczne. Łódź-Kraków: Wydawnictwo Uniwersytetu Łódzkiego, Universitas.

Mielczarek, Tomasz. 1994. „Funkcje prasy w systemie politycznym Drugiej Rzeczypospolitej”. Kieleckie Studia Bibliologiczne 2: 77-110.

Mierzecki, Władysław. 2000. „Praca zarobkowa kobiet w środowisku robotniczym w Polsce międzywojennej”. W Równe prawa i nierówne sz̧anse. Kobiety w Polsce międzywojennej. Red. Anna Żarnowska, Andrzej Szwarc. Warszawa: Wydawnictwo DiG.

Nederveen Meerkerk Elise van, Silke Neunsinger Silke i Dirk Hoerder. 2015. "Domestic Workers of the World: Histories of Domestic Work as Global Labor History." W Towards a Global History of Domestic and Caregiving Workers. Red. Dirk Hoerder, Elise van Nederveen Meerkerk, Silke Neunsinger. Leiden-Boston: Brill.

Perec, Icchok Lejb. 1958. Wybór opowiadań. Tłum. Anna Dresnerowa. Wrocław: Zakład Narodowy Imienia Ossolińskich.

Perrot, Michelle. 1998. Les femmes ou les silences de l'bistoire. Paris: Flammarion.

Piotrowska-Marchewa, Monika. 2009. „Pod patronatem Kościoła i w ogniu walki klasowej. Z problematyki związków zawodowych żeńskiej służby domowej w II Rzeczypospolitej. Rekonesans". W Driałaczki społeczne, feministki, obywatelki... Samoorganizowanie sie kobiet na ziemiach polskich wXX w. (na tle porównawcrym). T.2. Red. Agnieszka Janiak-Jasińska, Katarzyna Sierakowska, Andrzej Szwarc. Warszawa: Neriton.

Poniat, Radosław. 2014. Stų̧ba domowa w miastach na ziemiach polskich od połowy XVIII do końca XIX wieku. Warszawa: Wydawnictwo DiG.

Power, Eileen. 1924. Medieval People. London: Methuen \& Co.

Rancière, Jacques. 1981. La Nuit des prolétaires. Archives du rêve ouvrier. Paris: Fayard.

Ringelblum, Emanuel. 1933. „Stosunki gospodarcze i społeczne Żydów w Polsce w drugiej połowie XVIII wieku". Miesięcznik Żydowski 11/12: 227-235.

Ringelblum, Emanuel. 1988. Kronika getta warsæawskiego. Tłum. Adam Rutkowski. Warszawa: Czytelnik.

Sarti, Raffaella. 2015. "Historians, Social Scientists, Servants and Domestic Workers: Fifty Years of Research on Domestic and Care Work." W Towards a Global History of Domestic and Caregiving Workers. Red. Dirk Hoerder, Elise van Nederveen Meerkerk, Silke Neunsinger. Leiden-Boston: Brill.

Schiper, Ignacy. 1911. Studya nad stosunkami gospodarcsymi Żydów w Polsce podczas średniowiecza. Lwów: [b.d].

Toruńczyk, Romana. 1961. Z dziejów rewolucyjnej walki młodzieşy w latach 1929-1933. Warszawa: Iskry.

Trocki, Lew. 1991. Zdradzona rewolucja. Caym jest ZSRR $i$ dokad zmierz̨a?. Tłum. Aleksander Achmatowicz. Pruszków: Wibet. 
Wipszycka, Ewa. 1994. Kościót w świecie późnego antyku. Warszawa: Państwowy Instytut Wydawniczy.

Witowska, Józefa. 1951. Ludzie i nieludzie. Ze wspomnień stużacej. Warszawa: Państwowy Instytut Wydawniczy.

Zalewska, Gabriela. 1996. Ludność šydowska w Warszawie w okresie miedzywojennym. Warszawa: Wydawnictwo Naukowe PWN.

Zemon Davis, Natalie. Kobiety na marginesach. Tray siedemnastowieczne ṡyciorysy. Tłum. Bartosz Hlebowicz. Warszawa: Wydawnictwo Naukowe PWN.

Żarnowski, Janusz. 1999. „Służba domowa”. W Encyklopedia historii Drugiej Rzeczypospolitej. Red. Andrzej Garlicki. Warszawa: Wiedza Powszechna, Bellona.

Żarnowski, Janusz. 2000. „Kobiety w strukturze społeczno-zawodowej Polski międzywojennej”. W Równe prawa i nierówne szanse. Kobiety w Polsce międzywojennej. Red. Anna Żarnowska, Andrzej Szwarc. Warszawa: Wydawnictwo DiG. 
Piotr Laskowski - historyk idei, pracuje w Instytucie Stosowanych Nauk Społecznych UW w Katedrze Historii Idei i Antropologii Kulturowej. Opublikował Szkice z dziejón anarchizmu (Warszawa 2006, 2007) i Maszyny wojenne. Georges Sorel i strategie radykalnej filozofii politycznej (Warszawa 2011). Przygotował redakcję naukowa pism Jana Wacława Machajskiego (Pracownik umystowy $i$ inne pisma, Warszawa 2016) oraz - z Sebastianem Matuszewskim dwóch tomów konspiracyjnej prasy żydowskiej zachowanej w Archiwum Ringelbluma (Prasa getta warszawskiego: Hechaluc-Dror i Gordonia, Warszawa 2015; Prasa getta warszawskiego: radykalna lewica niesyjonistyczna, Warszawa 2016).

\section{DANE ADRESOWE:}

Katedra Historii Idei i Antropologii Kulturowej

Instytut Stosowanych Nauk Społecznych UW

ul. Żurawia 4

00-503 Warszawa

EMAIL: ptrlaskowski@gmail.com

CYTOWANIE: Laskowski, Piotr. 2017. „'Zaczęłam filozofować, rozmyślać, szukać odpowiedzi na dręczące mnie kwestie'. Wspomnienia Edwardy (Etli) Bomsztyk: biografia, emancypacja, polityka." Praktyka Teoretycz̨na 1(23): 84-129.

DOI: $10.14746 /$ prt.2017.1.4

\section{AUTHOR: Piotr Laskowski}

TITLE: "I began to philosophize, to meditate, to seek answers to the issues that troubled me.” Recollections of Edwarda (Etla) Bomsztyk: Biography, Emancipation, Politics

ABSTRACT: This paper presents three autobiographical accounts by Etla (Edwarda) Bomsztyk (1899-1973), a Jewish house maid. Two of these unique testimonies (one published in Yiddish in 1959, the other recorded in Polish in 1966) focus on Bomsztyk's political activity. This activity encompasses organizing domestic servants into unions in Warsaw in the 1920s, membership in the Bund and the Communist Party of Poland, and political imprisonment. The third account, written in Polish in 1953 and never before published, sits outside any institutional context. This consists in a personal narration on childhood in a small-town Jewish family, migration to Warsaw, poverty and suffering, first readings, loneliness and revolt. The aim of this paper is to reveal the tension that exists between these three texts. That is, between two accounts of political militancy on the one 
hand, and with early experiences that, though a prerequisite for Bomsztyk's later political engagement, nevertheless could not be fully articulated within communist party discourse.

KEYWORDS: Edwarda (Etla) Bomsztyk, domestic servants, people’s history, Jewish history, women's history 